\title{
UNESCO Dünya Mirası Listesindeki Destinasyonların Yer Aldığı illerin Turizm Potansiyelinin Değerlendirilmesi
}

\author{
Talip Arsu ${ }^{1 * *}$ (D) Serap Serin Karacaer 2 iD \\ ${ }^{1}$ Aksaray Üniversitesi, Sosyal Bilimler Meslek Yüksekokulu, Aksaray, Türkiye, taliparsu@aksaray.edu.tr, ORCID: 0000-0002-2580-166X \\ ${ }^{2}$ Aksaray Üniversitesi, Sosyal Bilimler Meslek Yüksekokulu, Aksaray, Türkiye, sskaracaer@gmail.com, ORCID: 0000-0001-6730-2028
}

Öz

1980'li yıllar ile birlikte turizm endüstrisinde yaşanan gelişmeler ve buna bağlı olarak tüketici tercihlerinde meydana gelen değişimler sonucunda turizm endüstrisinde 35 olarak kabul edilen "deniz-kum-güneş (sea-sand-sun)" turizminin meydana getirdiği kitle turizmi anlayışının, yerini çeşitli faaliyetler ve farklı deneyimler sunan alternatif turizm olanaklarına bıraktığı görülmektedir. Bu bağlamda "kültür" odaklı gerçekleştirilen aktiviteler çerçevesinde şekillenen "kültürel miras turizmi" faaliyetlerinin, destinasyonlar açısından öne çıkan alternatif turizm olanaklarından birisi olduğunu ifade etmek mümkündür. Bu noktadan hareketle bu çalışmada, UNESCO Dünya Mirası Listesinde yer alan ve dolayısıyla da kültürel miras turizmi olanaklarına sahip destinasyonların bulunduğu illerin turizm potansiyellerinin değerlendirilmesi amaçlanmıştır. Bu değerlendirme gerçekleştirilirken Çok Kriterli Karar Verme (ÇKKV) yöntemlerinden CRITIC ve MAIRCA kullanılmıştır. Öncelikle kriterler objektif bir ÇKKV yöntemi olan CRITIC kullanılarak ağırlıklandırılmıştır. Sekiz kriterin kullanıldığı çalışmada en önemli kriterler sırasıyla yatak sayısı, otel sayısı ve müze sayısı olarak bulunmuştur. CRITIC yöntemi ile ulaşılan kriter ağırlıkları kullanılarak MAIRCA yöntemi ile iller sıralanmıştır. Turizm potansiyeli açısından sırasıyla en başarılı iller Istanbul, Muğla, Izmir, Bursa ve Aydın, en başarısız iller ise Karabük, Sivas, Kars, Çorum ve Adıyaman olmuştur. Son olarak kullanılan ÇKKV yöntemlerinin tutarlıı̆̆ını ve doğruluğunu test etmek için duyarlılık analizi yapılmıştır.

Anahtar Kelimeler: UNESCO Dünya Mirası, Kültür Turizmi, CRITIC, MAIRCA

Cilt 5, Sayı 2, 2021

ss. $346-370$

Evaluating the Tourism Potential of the Cities Where the Destinations Located on the UNESCO World Heritage List

\section{Abstract}

The mass tourism understanding created by "sea-sand-sun" tourism, which is accepted as 35 in the tourism industry recently, it is seen that has been replaced by alternative tourism opportunities that offer various activities and different experiences. In this context, it is possible to state that "cultural heritage tourism" activities shaped within the framework of activities focused on "culture" are one of the prominent alternative tourism opportunities in terms of destinations. From this point of view, in this study, it was aimed to evaluate the tourism potential of the cities that are included in the UNESCO World Heritage List and therefore have cultural heritage tourism opportunities. While performing this evaluation, CRITIC and MAIRCA, which are among the Multi Criteria Decision Making (MCDM) methods, were used. First of all, criteria were weighted using CRITIC, which is an objective MCDM method. In the study where eight criteria were used, the most important criteria were found to be the number of beds, the number of hotels and the number of museums, respectively. Cities were ranked by MAIRCA method by using criterion weights obtained by CRITIC method. In terms of tourism potential, the most successful cities were Istanbul, Muğla, Izmir, Bursa and Aydın, and the most unsuccessful cities were Karabük, Sivas, Kars, Çorum and Adıyaman, respectively. Finally, sensitivity analysis was performed to test the consistency and accuracy of the MCDM methods used.

Keywords: UNESCO World Heritage, Cultural Tourism, CRITIC MAIRCA
Research Article

Vol 5, No 2, 2021

pp. $346-370$

Received : 18.05.2021

Revision1: 07.07.2021

Revision2: 02.08.2021

Accepted: 07.08.2021

\section{Önerilen Atıf/Suggested Citation}

Arsu, T. ve Serin Karacaer, S. (2021). UNESCO Dünya Mirası Listesindeki Destinasyonların Yer Aldığı illerin Turizm Potansiyelinin Değerlendirilmesi. Güncel Turizm Araştırmaları Dergisi, 5(2), 346-370.

**Sorumlu yazar e-posta: taliparsu@aksaray.edu.tr 


\section{GíRIŞ}

"Kültür" olgusu, geçmişi M.Ö. 4000'de yazıyı ve tekerleği ilk bulan ve kullanan Sümerlere kadar dayanan turizmin (Goeldner ve Ritchie, 2009: 37) her döneminde vazgeçilmez unsurlarından birisi olmuştur. Kültür insanlığın başlangıcından günümüze kadarki süreçte bireyler ya da toplumlar tarafından düşünülen (tavır, inanç, değer, fikir vb.), yapılan (yaşayış şekli, davranış, tutum vb.) ve oluşturulan (sanat eseri, el sanatı vb.) birçok faaliyeti içermektedir. Dolayısıyla kültür, süreçler (insanların düşünceleri ve yaşama biçimleri) ve bu süreçler sonunda oluşan ürünlerden (binalar, el sanatları, sanat ve gelenekler) oluşan bir bütündür (Richards, 2001: 7). Seyahat etme, bu seyahatler sırasında farklı mekânlar ve insanlar tanıma ve onların kültürlerini öğrenme arzusu, bireyler için her zaman çok güçlü bir güdü olmuştur (Jafari, 2002: 125). Bu bağlamda turistik tüketicilerin kültürel unsurlar olarak değerlendirilen alanlara yönelik gerçekleştirdikleri ziyaretler ile şekillenen kültür turizminin, son dönemlerde hızlı gelişme gösteren alt dallarından birisi de kültürel miras turizmidir. "Yeryüzü üzerindeki en büyük gösteri olarak tanımlanan turizmin, hayat kaynağı mirastır" (Boniface ve Fowler, 2002: xi). Birleşmiş Milletler Eğitim, Bilim ve Kültür Örgütü (UNESCO) miras kavramını; geçmişten gelen varlı̆̆ımız, bugün yaşadığımız şey ve gelecek nesillere aktardıklarımız olarak tanımlamaktadır. İnsanlık için olağanüstü değer taşıdığı düşünülen dünya çapında kültürel ve doğal mirasın tanımlanmasını ve korunmasını teşvik etmeyi amaçlayan UNESCO, kültürel ve doğal mirasın yeri doldurulamaz bir ilham kaynağı olduğunu beyan etmektedir. UNESCO'ya (2021) göre Dünya Mirası" kavramını istisnai kılan, evrensel olarak uygulanmasıdır. Başka bir ifade ile söz konusu alanlar bulundukları bölgeye bakılmaksızın dünyanın tüm halklarına aittir.

Dünya Turizm Örgütü (UNWTO), turizmin ana motivasyonlarından birinin, insanoğlunun doğasında olan merakı ve dünyadaki kültürel kimlikleri keşfetme arzusu olduğunu vurgulamaktadır. UNWTO'ya (2021) göre doğal manzaralar ve yeniden canlandırılmış tarihi kentler dahil olmak üzere doğal ve kültürel miras alanları, bir destinasyonu diğerinden ayıran değerli turizm varlıklarıdır. Dolayısıyla her geçen yıl dünya üzerinde seyahat eden insan sayısının giderek arttığı ve bununla birlikte turistik tüketicilerin gidilecek destinasyonlara ilişkin değişen eğilimleri düşünüldüğünde, miras çekicilikleri olarak değerlendirilen ve UNESCO tarafından Dünya Miras Listesi'ne alınan kültürel ve doğal unsurlara sahip destinasyonların turizm potansiyeli açısından değerlendirilmesi de bir gereklilik haline gelmiştir. Bu bağlamda çalışma kapsamında; Türkiye'de UNESCO Dünya Mirası listesinde yer alan destinasyonların bulunduğu illerin Çok Kriterli Karar Verme (ÇKKV) yöntemleri ile değerlendirilmesi amaçlanmıştır. İller değerlendirilirken ÇKKV yöntemlerinden CRITIC (CRiteria Importance Through Intercriteria Correlation) ve MAIRCA (MultiAttributive Ideal-Real Comparative Analysis) kullanılmıştır. Literatür dikkate alınarak seçilen kriterleri ağırlıklandırmak için kullanılan CRITIC yönteminin tercih edilmesinin sebebi kriterler arası korelasyon değerlerinin kullanılması ve uzman görüşüne ihtiyaç duyulmamasından dolayı objektif ağırlıklar hesaplanabilmesidir. Çünkü illeri değerlendirmek için seçilen kriterler için oluşturulan kriterler arası ilişki 
matrisi (Tablo 4) incelendiğinde kriterler arasında anlamlı korelasyon değerleri olduğu gözlemlenmektedir. Kriterler arasındaki bu anlamlı korelasyonlar kriterlerden elde edilen toplam bilgiyi artıracağından dolayı CRITIC yöntemi kullanılmıştır. Ayrıca CRITIC yöntemi uzman görüşüne ihtiyaç duymaması sebebiyle subjektif görüşlerden kaynaklanabilecek insan hatasını ortadan kaldırmaktadır. MAIRCA yöntemi de bir taraftan karar alternatiflerini değerlendirirken bir taraftan da ideal değerlere yakınlığ (karar alternatifleri için en uygun değer) dikkate almasından dolayı tercih edilmiştir. MAIRCA yöntemi sonucunda ulaşılan bilgilerin doğruluğunu ve tutarlılığını test etmek için (duyarlılık analizi) CRITIC ağırlıkları kullanılarak model farklı ÇKKV yöntemleri ile tekrar çözülmüştür.

Araştırma tasarlanırken öncelikle ayrıntılı bir kavramsal çerçeve ve literatür incelemesi sunulmuştur. Sonrasında araştırmanın amacı ve önemi verilerek araştırma kriterlerinin nasıl belirlendiği üzerinde durulmuştur. Değerlendirmede kullanılan CRITIC ve MAIRCA yöntemleri tanıtıldıktan sonra araştırmada ulaşılan bulgular paylaşılmıştır. Son olarak duyarlılık analizi bölümünde çözümün tutarlılı̆̆ test edilerek, sonuç ve tartışma bölümünde ulaşılan bulgular değerlendirilmiştir.

\section{Kavramsal Çerçeve}

Son yıllarda kültürel değerlere sahip ülkeler açısından önemli bir alternatif turizm çeşidi olarak kabul edilen kültür turizmi; insanların sürekli yaşadıkları yerden kültürel ihtiyaçlarını karşılamak, çeşitli deneyimler kazanmak ve yeni birtakım bilgiler elde etmek amaciyla kültürel çekiciliklere sahip destinasyonlara hareket etme durumudur (Bachleitner ve Zins, 1999: 199). Başka bir ifade ile kültür turizmi; değişik kültürleri ve kültür eserlerini (tarihsel yapılar, müzeler, ören yerleri, savaş alanları vb.) görmek, eğlence ya da toplantı amaçlı (festival, şenlik, kongre, fuar vb.) etkinliklere katılmak, yerel lezzetleri tecrübe etmek, dini seyahatlerde bulunmak, yerel toplulukların yaşam şekillerini deneyimlemek gibi motivasyon unsurları ile hareket eden turistlerin katılımıyla gerçekleşen bir turizm çeşididir (Medlik, 2003: 48; Usta, 2009: 12; Çulha, 2008; Hazar, 2010: 68).

UNWTO (2021) kültür turizmini; “ziyaretçinin temel motivasyonunun, bir turizm destinasyonundaki somut ve somut olmayan kültürel cazibe merkezlerini öğrenmek, keşfetmek, deneyimlemek ve tüketmek olduğu bir tür turizm etkinliği" olarak tanımlamaktadır. Bununla birlikte kültür turizmi kapsamında yer alan cazibe merkezlerinin çekicilik kaynağının ise sanat ve mimari, tarih ve kültürel miras, mutfak mirası, edebiyat, inançlar ve gelenekler, müzik, yaratıcı endüstriler, yaşam tarzları ve değerler gibi yaşayan kültürleri kapsayan bir toplumun ayırt edici materyal, entelektüel, manevi ve duygusal özellikleriyle ilgili olduğuna da vurgu yapmaktadır. Son dönemlerde turistik tüketicilerin turistik ürünlere yönelik değişen tercihleri ve gelişen bakış açıları dikkate alındığında kültürel turizmin kaynaklarını; (1) tarihsel olaylar ve ünlü insanlar, (2) modern kültür, (3) temalı etkinlikler ve gezi programları, (4) yerel yiyecek ve içecekler, (5) özel ilgi seyahatleri, (6) sportif ve boş zaman faaliyetleri, (7) yerel el sanatları, (8) sanatsal faaliyetler, (9) mimari çeşitlilik, (10) endüstri ve ticaret, (11) lisan, (12) inanç merkezleri, (13) festivaller ve özel olaylar ve 
(14) miras çekicilikleri oluşturmaktadır (Richards, 2001: 23). Söz konusu kaynakların her biri turistik motivasyon unsuru olarak önem arz etmekle birlikte günümüzde özellikle UNWTO ve UNESCO gibi Birleşmiş Milletlere bağlı ve uluslararası düzeyde çalışmalar yapan kuruluşların da üzerinde durduğu "miras çekicileri" ön plana çıkmaktadır. Müzeler, kaleler, malikâneler, antik anıtlar, tarihi bahçeler, manzara bahçeleri, tarihi köyler, tarihi sit alanları vb. unsurları içeren "kültürel miras çekicilikleri" ni; bir toplumun ortak geçmişini anlatan, toplumun dayanışma ve birlik duygularını güçlendiren, insanların tarih boyunca biriktirdikleri deneyimlerin ve geleneklerin devamlılığını sağlayan ve geleceklerini şekillendirmelerinde yardımcı olan değerler olarak açıklamak mümkündür (Öksüz Kuşçuoğlu ve Taş, 2017). Kültürel miras çekiciliklerini oluşturan her bir unsurun, yeni ve farklı olanı tanımak ve deneyimlemek arzusunda olan turistik tüketiciler için seyahatin başlica motivasyonlarından olduğunu ifade etmek mümkündür. Dolayısıyla söz konusu motivasyon ile şekillenen kültürel miras turizmi kapsamında; tarihi, mimari ve sanatsal açıdan önemli anıtlar ve arkeolojik yapılar ile modern zamanlarda yapılmış ancak toplum tarafından kabul görmüş soyut ve somut varliklar değerlendirilmektedir (Aksoy ve Ünsal, 2012: 3). Kültürel miras turizmi; geçmişteki toplumların ekonomik, sosyal ve politik yönlerini günümüze tarihi öğretilerle yansitan kültürel değerlerdir (Khakzad, Pieters ve Van Balen, 2015: 111). Bu noktadan hareketle kültürel miras turizmi faaliyetlerinin en önemli amaçlarından birisinin, sahip olunan mirasın gelecek nesillere aktarılması olduğunu ifade etmek mümkündür.

UNESCO; Birleşmiş Milletler eğitim, bilim ve kültür örgütüdür. UNESCO'nun amac1; eğitim, bilim ve kültür alanlarında uluslararası iş birliği yoluyla barışı inşa etmeye çalışmaktır. UNESCO (2021), dünyada bazı yerlerin “dünya mirası” olduğu ve bu yerlere sahip çıkılması gerektiğine dikkat çekmektedir. Üstün evrensel değere sahip, insanlığın ortak mirası olarak kabul edilen kültürel ve doğal varlıkları dünyaya tanıtmak, söz konusu evrensel mirasa sahip çıkacak bilinci oluşturmak ve farklı sebeplerle bozulan, yok olan kültürel ve doğal değerlerin korunması için gerekli iş birliğini sağlamak amacıyla UNESCO'nun 1972 yılında Paris'te yapılan genel konferansında; sorunun uluslararası bir sözleşme konusu yapılmasına karar verilmiş ve "Dünya Kültürel ve Doğal Mirasının Korunmasına Dair Sözleşme" kabul edilmiştir. Sözleşme ile birlikte 1976 yılında Dünya Miras Komitesi oluşturulmuş, 1978 yılında da kültürel ve doğal miraslar için Dünya Miras Listesi hazırlanmaya başlanılmıştır. Türkiye bu sözleşmeye taraf olmayı 1982 yılında onaylamış ve 1983 yılında da söz konusu sözleşme Türkiye'de yürürlüğe girmiştir (İstanbul Tarihi Alanları Alan Başkanlığı).

Dünya Kültürel ve Doğal Mirasının Korunmasına Dair Sözleşme’ye göre “Üstün Evrensel Değerlere Sahip Eserler" üç başlık altında kategorize edilmiştir. Buna göre; anıtlar (tarih, sanat veya bilim açısından üstün evrensel değere sahip mimari eserler, anıtsal heykel ve resim çalışmaları, arkeolojik nitelikteki unsurlar veya yapılar, yazıtlar, mağaralar), yapı toplulukları (mimarileri, homojenlikleri veya peyzajdaki yerleri nedeniyle tarih, sanat veya bilim açısından üstün evrensel değere sahip ayrı 
veya bağlantılı yapı toplulukları) ve sit alanları (insan ürünü veya doğa ile insanın ortak eserleri olan tarihi, estetik, etnolojik veya antropolojik bakış açılarından üstün evrensel değere sahip arkeolojik alanlar) "Kültürel Miras" olarak kabul edilmiştir. Estetik veya bilimsel açıdan üstün evrensel değere sahip fiziksel ve biyolojik oluşumlardan veya bu tür oluşum gruplarından oluşan doğal özellikler; bilim veya koruma açısından üstün evrensel değere sahip tehdit altındaki hayvan ve bitki türlerinin habitatını oluşturan jeolojik ve fizyografik oluşumlar; bilim, koruma veya doğal güzellik açısından üstün evrensel değere sahip doğal alanlar “Doğal Miras” olarak kabul edilmiştir. Hem kültürel hem de doğal miras tanımlarının bir kısmını veya tamamını karşılayan varlıklar ise "Karma Kültürel ve Doğal Miras" olarak kabul edilmiştir (Operational Guidelines for the Implementation of the World Heritage Convention, 2019).

2021 yılı itibariyle dünya genelinde 167 ülkede UNESCO Dünya Miras Listesi'ne kayıtlı 1121 varlık bulunmaktadır. Bu varlıklardan 869'u kültürel miras, 213'ü doğal miras, 39'u ise karma miras (kültürel ve doğal) niteliğindedir. Söz konusu listede Türkiye ise 16'sı kültürel miras, ikisi de karma miras (Göreme Milli Parkı ve Kapadokya Kaya Alanları, Hierapolis-Pamukkale) olmak üzere toplamda 17 farklı destinasyonda 18 varlık ile yer almaktadır (UNESCO, 2021). Tablo 1'de Türkiye'deki kültürel ve karma miras listesi gösterilmiştir.

Tablo 1. Türkiye' deki kültürel ve karma miras listesi

\begin{tabular}{|c|c|c|}
\hline Varlık Adı & Bulunduğu İl & $\begin{array}{c}\text { Listeye Giriş } \\
Y_{1} l_{1}\end{array}$ \\
\hline Göreme Milli Parkı ve Kapadokya Kaya Alanları & Nevşehir & 1985 \\
\hline Divriği Ulu Camii ve Darüşşifası & Sivas & 1985 \\
\hline İstanbul'un Tarihi Alanları & İstanbul & 1985 \\
\hline Hattuşa: Hitit Başkenti & Çorum & 1986 \\
\hline Nemrut Dağ̀ & Adiyaman & 1987 \\
\hline Hierapolis-Pamukkale & Denizli & 1988 \\
\hline Xanthos-Letoon & Antalya-Muğla & 1988 \\
\hline Safranbolu Şehri & Karabük & 1994 \\
\hline Truva Arkeolojik Alanı & Çanakkale & 1998 \\
\hline Edirne Selimiye Camii ve Külliyesi & Edirne & 2011 \\
\hline Çatalhöyük Neolitik Alanı & Konya & 2012 \\
\hline Bursa ve Cumalıkızık; Osmanlı İmparatorluğunun Doğuşu & Bursa & 2014 \\
\hline Bergama ve Çok Katmanlı Kültürel Peyzaj Alanı & İzmir & 2014 \\
\hline Diyarbakır Kalesi ve Hevsel Bahçeleri Kültürel Peyzajı & Diyarbakır & 2015 \\
\hline Efes & İzmir & 2015 \\
\hline Ani Arkeolojik Alanı & Kars & 2016 \\
\hline Aphrodisias & Aydin & 2017 \\
\hline Göbeklitepe & Şanlıurfa & 2018 \\
\hline
\end{tabular}




\section{Literatür Taraması}

Çalışma kapsamında kültürel miras, miras turizmi, UNESCO dünya mirasları kavramları üzerinden yapılan literatür taramasında gerek ulusal gerekse de uluslararası alan yazınında farklı bakış açıları ve yöntemlerle yapılmış birçok çalışmaya ulaşmak mümkün olmuştur. Bu noktada özellikle çalışmanın amacı olan "söz konusu miras çekiciliklerinin bulunduğu destinasyonlardaki turizm potansiyeline etkileri ya da katkıları" konusuna en yakın çalışmalardan çıkan sonuçlar irdelenmiştir. Uslu ve Kiper (2006); turizmin farklı kültürlerin tanınması noktasında önemli bir araç olduğu, toplumların farklı kültürlerle etkileşimi sonucunda değişimin kaçınılmaz bir süreç haline geldiği ve bu süreçlerde turizmin tüm paydaşlarının kültürel çeşitliliği ve özgünlüğü sürdürmeyi hedeflemeleri gerekliliğine vurgu yapmaktadır. Meydan Uygur ve Baykan'a (2007) göre doğal ve kültürel varlıklar, günümüz turistinin turizm faaliyetine katılmasına neden olan önemli bir faktör olduğundan, bir pazarlama aracı olarak kullanılabilmektedir. Türker ve Çelik (2012) miras turizminde temel amacın kültürel mirasın metaya dönüştürülmesi değil, korunması olduğuna vurgu yapmakla birlikte, bir kültürel mirasın ne kadar özenli sunulur ise turist tarafından da o kadar değerli algılanacağını belirtmektedir. Ayrıca günümüz turistleri, ziyaret ettikleri bölgelerin kültürel değerlerini sadece gözlemlemekle kalmayıp, deneyimlemek de istemektedir. Bandeoğlu (2015), bölgesel kalkınma açısından kültür turizmine daha fazla önem verilmesi gerekliliğine vurgu yapmaktadır. Sadece doğa koşullarına bağlı kalmaksızın kültür turizminin tüm yıla yayılarak, ülke kültürünün gerek yerli gerekse de yabancılara tanıtılması ve aynı zamanda geçmişin korunarak geleceğe sahip çıkılması noktasında da kültür turizminin geliştirilmesi önem arz etmektedir. Ayrıca turistik ürün çeşitlendirme ve markalaşmada da kültür turizmi önemli bir kaynak durumundadır.

Ceylan ve Somuncu (2016), 1994 yılında UNESCO dünya mirası listesine giren Safranbolu'nun kültürel miras kaynakları ve korunmasına ilişkin çalışmalarında, destinasyonda dünya miras alanı özelliklerinin korunması ile birlikte turizmin gelişebileceğini ifade etmektedir. Lopez-Guzman ve Santa-Cruz (2016) belirli bir bölgenin UNESCO tarafından dünya miras alanı olarak tanınması ile birlikte; alanın kültürel tanitımına ve korunmasına ek olarak turistik tüketicileri destinasyona çekmede önemli bir cazibe unsuru olacağı ve dolayısıyla bu alanların yönetiminin önemsenmesi gerekliliğini vurgulamaktadır. Öksüz Kuşçuoğlu ve Taş'a (2017) göre destinasyonlarda bulunan kültür mirası değerinin fiziki olarak korunması ile birlikte bu değerin yerel toplum tarafından anlaşılması için de yol gösterici olunmalıdır. Bu bağlamda kültürel miras değerlerinin destinasyonun sosyal ve ekonomik gelişimi ve aynı zamanda eğitsel açıdan bilgi kaynağı olarak taşıdıkları önem ve neden korunması gerektiği konusundaki bilinci arttırmaya yönelik çalışmalar yapılmalıdır.

Yukarıda sıralanan ve kültürel miras çekiciliklerinin turizm faaliyetlerine ve destinasyon tanıtımına yönelik pozitif yönlü katkılarına değinen çalışmalara karşın, alan yazında irdelenen bazı çalışmalarda ise bu pozitifliğin söz konusu olmadığı görülmüştür. Cuccia, Guccio ve Rizzo (2016) kültürel mirasın turizm talebini 
artırmadaki etkilerini araştırmaya yönelik hazırladıkları çalışmada, turizm destinasyonlarının rekabet gücünün artırılmasında UNESCO Dünya Mirası Listesi'nin rolünü incelemişlerdir. Çalışmadan elde edilen sonuçlara göre kültürel ve doğal unsurlar, İtalyan turizm destinasyonlarının performansını olumlu yönde etkilerken, diğer taraftan UNESCO alanlarının varlığı ile destinasyonların verimliliği arasında negatif yönlü bir ilişki söz konusudur. Yenişehirlioğlu ve Arslan Kalay (2017) UNESCO Dünya Miras Listesi'nin kültürel miras alanlarındaki ziyaretçi sayılarına etkisini araştırmaya yönelik çalışmalarında söz konusu listede bulunan dünyadan ve Türkiye' den 6 örnek alanı incelemişlerdir. Çalışma kapsamında incelenen alanlardan 5'inde UNESCO Dünya Miras Listesi'ne girmelerinin ardından çok açık ve net şekilde görünen bir ziyaretçi artışı olmamıştır. Destinasyonlar önceki yıllarda sahip oldukları oransal artışı kısmen sürdürmüşler, Dünya Miras Listesi'ne dahil olmaları sadece küçük ve yukarı doğru kırılmalara yardımcı olmuştur. Dolayısıyla çalışmadan elde edilen bulgular sonucunda UNESCO Dünya Miras Listesi'nde yer almanın destinasyonlardaki ziyaretçi sayıları üzerinde doğrudan bir etkiye sahip olmadığını ifade etmek mümkündür. Çağlar ve Doğan (2018) çalışmalarında, Diyarbakır Kalesi ve Hevsel Bahçeleri Kültürel Peyzajı'nın UNESCO Dünya Miras Listesi'ne girmesi ile birlikte turizm olanaklarının gelişmesi, yeni istihdam olanakları sağlanması ve dünyaca tanınırlığının artması beklenen kentte, bu yönde ciddi gelişmeler yaşanmadı̆̆ını belirtmektedir.

Yapılan ayrıntılı literatür incelemesinde turizm potansiyelini inceleyen birçok çalışmaya da rastlanmıştır. Seçilmiş ve Sarı (2010) ile Kervankıran ve Sert Eteman (2020)'ın turizm gelişmişlik indeksi oluşturmaya yönelik temel bileşenler analizi kullanarak yaptığı çalışmaların yanında ÇKKV yöntemleri de turizm potansiyelini belirlemeye yönelik birçok çalışmada kullanılmıştır. Cracolici, Nijkamp ve Rietveld (2008) 103 İtalyan bölgesini değerlendirmek için Veri Zarflama Analizi (VZA), Baldemir ve Akyurt Kurnaz (2013) Muğla ve ilçelerini değerlendirmek için Analitik Hiyerarşi Prosesi (AHP), Genç ve Filipe (2016) Portekiz şehirlerini değerlendirmek için bulanik TOPSIS (Technique for Order Performance by Similarity to Ideal Solution), Martín, Mendoza ve Román (2017) 139 ülkeyi değerlendirmek için VZA ve Fedajev, Popović ve Stanujkić (2019) 13 Avrupa ülkesini değerlendirmek için EDAS (Evaluation Based on Distance from Average Solution) yöntemini kullanmıştır.

Literatürde yer alan turizm potansiyelini değerlendirildiği çalışmaların hiçbirinde kriter ağırlıklandırmak için bir yöntem kullanılmamıştır. Bu çalışmada ise kriterleri ağırlıklandırmak için Diakoulaki, Mavrotas ve Papayannakis (1995) tarafından önerilen ve klima seçimi (Vujičić, Papić ve Blagojević, 2017), risk değerlendirmesi (Ayrım ve Can, 2017), üçüncü parti lojistik servis sağlayıcısı seçimi (Keshavarz Ghorabaee, Amiri, Zavadskas ve Antuchevičienė, 2017), yapı ekipmanlarının değerlendirilmesi (Keshavarz Ghorabaee, Amiri, Zavadskas ve Antuchevičienè, 2018), finansal performans değerlendirmesi (Şenol ve Ulutaş, 2018), banka performans değerlendirmesi (Akbulut, 2019), kargo firması değerlendirmesi (Ulutaş ve Karaköy, 2019), kurumsal sürdürülebilirlik performansı analizi (Yalçın ve Karakaş, 2019), girişim sermayesi yatırım ortaklıkları değerlendirmesi (Apan ve Öztel, 2020), personel 
seçim süreci (Ayçin, 2020), ülkelerin Ar-Ge performansı değerlendirmesi (Orhan ve Aytekin, 2020), 5G endüstrisi değerlendirmesi (Peng, Zhang ve Luo, 2020) gibi birçok karar probleminde kullanılan CRITIC yöntemi tercih edilmiştir. CRITIC yöntemi ile ulaşılan ağırlıklar kullanılarak illerin turizm potansiyelini değerlendirmek için Pamučar, Vasin ve Lukovac (2014) tarafından literatüre kazandırılıp, Gigovič, Pamučar, Bajić ve Milićević (2016) tarafından isimlendirilen ve tedarikçi performansı değerlendirmesi (Chatterjee Pamučar ve Zavadskas, 2018), demiryolu hemzemin geçitleri değerlendirmesi (Pamučar, Lukovac, Božanić ve Komazec, 2018), menü değerlendirmesi (Arsić, Pamučar, Suknović ve Janošević, 2019), banka performansı değerlendirmesi (Ayçin ve Orçun, 2019), catering firması seçimi (Ulutaş, 2019), askeri kamp alanı seçimi (Božanić, Jurišić ve Erkić, 2020), ülkelerin iş sağlı̆̆1 ve güvenliği performans değerlendirmesi (Can ve Kıran, 2020), finansal performans değerlendirmesi (Ayçin ve Güçlü, 2020; Günay ve Ecer, 2020), havayolu firmalarının performans değerlendirmesi (Özdağoğlu, Keleş ve Işıldak, 2020) gibi karar problemlerinde kullanılan MAIRCA tercih edilmiştir. CRITIC ve MAIRCA yöntemleri literatürde ayrı ayrı kullanılmalarının yanında banka performanslarının değerlendirilmesi (Aydın, 2020; Bektaş, 2020), ülkelerinin makroekonomik performansının değerlendirilmesi (Belke, 2020), üretim sürecindeki operatörlerin ergonomik risk düzeylerinin değerlendirilmesi (Mamak Ekinci ve Can, 2018) gibi birçok karar probleminde de birlikte kullanılmıştır.

Konu ile ilgili yapılan ulusal ve uluslararası literatür incelemesinde UNESCO Dünya Mirası listesinde yer alan destinasyonların bulunduğu illerin turizm potansiyeli açısından bir değerlendirmeye rastlanmamıştır. Ayrıca literatürde CRITIC ve MAIRCA yöntemlerinin ayrı ayrı veya birlikte herhangi bir turizm potansiyeli değerlendirmesi çalışmasında kullanımına rastlanmamıştır. İlgili literatürde tespit edilen boşluklar bu çalışmanın özgün yanını ortaya koymaktadır.

\section{YÖNTEM}

Bu çalışmanın amacı UNESCO dünya mirası listesindeki destinasyonların yer aldığı illeri değerlendirmektir. 2019 yılında UNESCO tarafından belirlenen 1121 dünya mirası arasından 18 tanesi Türkiye'de yer almaktadır. Bu listede yer almak tek başına bir ülke için büyük bir onur kaynağı olmakla birlikte, bu mirası bir turizm fırsatına çevirmek de listede yer almak kadar önemlidir. Bu yüzden bu çalışmada elde edilen bulgular mirasın bulunduğu şehrin turizm potansiyelini ortaya koyması açısından önemli sonuçlar ortaya çıkarmıştır. Çünkü mirasın söz konusu ilde yer alması tek başına yeterli olamamakta, mirasın turistik bir talep yaratabilmesi için şehrin turizm olanaklarının elverişli olması gerekmektedir.

Araştırma amacını gerçekleştirmeye yönelik kriterler seçilirken literatürden ve uzmanların fikirlerinden yararlanılmıştır. Literatürde yer alan kriterler içerisinden seçim yapmak için turizm yönetimi alanında akademik çalışmaları olan üç uzmandan görüş alınmıştır. Seçilen kriterler, kriterlerin tanımlayıcı istatistiki bilgileri, kriterlerin daha önce kullanıldığı akademik çalışmalar ve kriterlere ait bilgilerin hangi kaynaktan sağlandı ̆̆ 1 Tablo 2'de gösterilmiştir. 
Tablo 2. Araştırmada kullanılan kriterler, kriterlere ait tanımlayıcı istatistiki bilgiler ve verinin kaynağ

\begin{tabular}{|c|c|c|c|c|c|c|}
\hline Kriterler & Ortalama & Std. Sap. & Maks. & Min. & Kaynak & Veri $^{*}$ \\
\hline Otel Sayısı $\left(C_{1}\right)$ & 350,11 & 540,53 & 2074 & 37 & $\begin{array}{l}\text { Seçilmiş ve Sarı (2010); Giritlioğlu, İpar } \\
\text { ve Özlü (2015); Do ve Shih (2016); } \\
\text { Fedajev vd. (2019); Kervankıran ve Sert } \\
\text { Eteman (2020); }\end{array}$ & KTB \\
\hline Yatak Sayısı $\left(\mathrm{C}_{2}\right)$ & 35993,70 & 60972,68 & 211140 & 2955 & $\begin{array}{l}\text { Cracolici (2008); Seçilmiş ve Sarı (2010); } \\
\text { Giritlioğlu vd. (2015); Martin vd. (2017); } \\
\text { Fedajev vd. (2019); Kervankıran ve Sert } \\
\text { Eteman (2020); }\end{array}$ & KTB \\
\hline $\begin{array}{l}\text { Spor-eğlence ve } \\
\text { dinlence işyeri } \\
\text { sayıs1 }\left(\mathrm{C}_{3}\right)\end{array}$ & 295,1 & 693,56 & 2904 & 14 & $\begin{array}{l}\text { Baldemir ve Akyurt Kurnaz (2013); } \\
\text { Kervankıran ve Sert Eteman (2020); }\end{array}$ & SGK \\
\hline $\begin{array}{l}\text { Seyahat acentesi } \\
\text { tur operatörü } \\
\text { işyeri sayısı }\left(\mathrm{C}_{4}\right)\end{array}$ & 335,58 & 904,81 & 3808 & 9 & $\begin{array}{l}\text { Baldemir ve Akyurt Kurnaz (2013); Do } \\
\text { ve Shih (2016); Seçilmiş ve Sarı (2010); } \\
\text { Kervankıran ve Sert Eteman (2020); }\end{array}$ & SGK \\
\hline $\begin{array}{l}\text { Yiyecek içecek } \\
\text { işyeri sayısı }\left(\mathrm{C}_{5}\right)\end{array}$ & 3940,88 & 8240,09 & 34399 & 180 & $\begin{array}{l}\text { Baldemir ve Akyurt Kurnaz (2013); } \\
\text { Kervankıran ve Sert Eteman (2020); }\end{array}$ & SGK \\
\hline Müze sayısı $\left(\mathrm{C}_{6}\right)$ & 12,76 & 17,89 & 75 & 1 & $\begin{array}{l}\text { Cracolici (2008); Martin vd. (2017); } \\
\text { Fedajev vd. (2019); Kervankıran ve Sert } \\
\text { Eteman (2020); }\end{array}$ & TUIK \\
\hline $\begin{array}{l}\text { Tarihi yapı ve sit } \\
\text { alanları sayısı }\left(C_{7}\right)\end{array}$ & 4233,35 & 7476,35 & 32176 & 355 & $\begin{array}{l}\text { Cracolici (2008); Baldemir ve Akyurt } \\
\text { Kurnaz (2013); Martin vd. (2017); } \\
\text { Fedajev vd. (2019); Kervankıran ve Sert } \\
\text { Eteman (2020); }\end{array}$ & TUIK \\
\hline $\begin{array}{l}1 \text { yıldaki uçuş } \\
\text { sayısı }\left(C_{8}\right)\end{array}$ & 50074,64 & 162503,13 & 676368 & 314 & $\begin{array}{l}\text { Dwyer ve Kim (2003); Genç ve Filipe } \\
\text { (2016); Kervankıran ve Sert Eteman } \\
\text { (2020); }\end{array}$ & DHMI \\
\hline
\end{tabular}

${ }^{*}$ KTB: Kültür ve Turizm Bakanlığ 1

SGK: Sosyal Güvenlik Kurumu

TUİK: Türkiye İstatistik Kurumu

DHMI: Devlet Hava Meydanları İşletmesi Genel Müdürlüğü

Tablo 2' de gösterilen kriterler belirlendikten sonra UNESCO dünya mirası listesindeki destinasyonların bulunduğu illeri değerlendirmek için öncelikle seçilen kriterler CRITIC yöntemi ile ağırlıklandırılmıştır. Sonra ise MAIRCA yöntemi ile iller değerlendirilmiştir.

\section{CRITIC}

Uzman görüşü içermediğinden dolayı "objektif ağırlıklar" oluşturmaya yarayan CRITIC yönteminde ağırlıklar, her bir kriterin kontrast yoğunluğunu ve kriterler arasındaki çatışmayı içermektedir. CRITIC yönteminde kriterler arası çatışma korelasyon katsayısı ile ölçülürken, kontrast yoğunluğu standart sapma ile değerlendirilir (Ghorabaee vd., 2018). CRITIC yöntemi farklı kaynaklarda farklı sayıda adım içermekle birlikte genellikle beş adımda tanımlanmıştır (Diakoulaki vd., 1995: 764-765; Keshavarz Ghorabaee vd., 2017: 69; Akbulut, 2019: 254-255; Xu, Ke, Li, Chu ve $\mathrm{Wu}, 2020: 69$; Ayçin, 2020: 4-5). 


\section{Adım 1. Karar matrisinin oluşturulması}

ÇKKV yöntemlerinin tümünde olduğu gibi CRITIC'de de ilk adımda karar matrisi oluşturulmaktadır. $n$ kriter ve $m$ alternatiften oluşan ve $X$ olarak adlandırılan karar matrisi Eşitlik (1)'de gösterildiği şekilde oluşturulmaktadır.

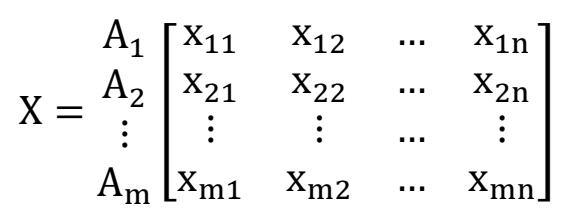

Eşitlik (1)'de bulunan $x_{i j}$ değerleri, j. değerlendirme kriterine göre i. alternatifin aldığ 1 değerleri ifade etmektedir. ( $\mathrm{j}$ değerlendirme kriteri sayısı $j=1,2, \ldots, n$ i ise karar alternatifi sayısı $i=1,2, \ldots, m$;).

\section{Adım 2. Normalize karar matrisinin oluşturulması}

Genellikle aynı birim cinsinden ifade edilmeyen kriter değerlerini [0,1] aralığına indirgemek için kriterlere normalizasyon işlemi uygulanmaktadır. Bu yüzden ikinci adımda maksimizasyon yönlü (fayda) ve minimizasyon yönlü (maliyet) kriterler sırasıyla Eşitlik (2) ve Eşitlik (3) kullanılarak normalize edilir.

$$
\begin{aligned}
& r_{i j}=\frac{x_{i j}-x_{j}^{-}}{x_{j}^{*}-x_{j}^{-}} \\
& r_{i j}=\frac{x_{j}^{*}-x_{i j}}{x_{j}^{*}-x_{j}^{-}}
\end{aligned}
$$

Eşitlik (2) ve Eşitlik (3) hesaplanırken kullanılan $x_{j}^{-}$ilgili kriterdeki en küçük değeri ifade ederken $x_{j}^{*}$ ise en büyük değeri ifade etmektedir.

\section{Adım 3. Korelasyon katsayı matrisinin oluşturulması}

Üçüncü adımda Eşitlik (4) kullanılarak kriter çiftleri arası doğrusal korelasyon katsayıları $\left(\rho_{j k}\right)$ hesaplanmaktadır. Çünkü CRITIC yöntemi kriter çiftleri arası ilişkilere dayanmaktadır. Sonrasında hesaplanan korelasyon katsayıları ile korelasyon katsayı matrisi oluşturulmaktadır.

$$
\rho_{j k}=\sum_{i=1}^{m}\left(r_{i j}-\overline{r_{j}}\right) \cdot\left(r_{i k}-\overline{r_{k}}\right) / \sqrt{\sum_{i=1}^{m}\left(r_{i j}-\overline{r_{J}}\right)^{2} \cdot \sum_{i=1}^{m}\left(r_{i k}-\overline{r_{k}}\right)^{2}} \quad k=1,2, \ldots, n
$$

\section{Adım 4. Toplam bilgi ölçüsünün $\left(H_{j}\right)$ hesaplanması}

Kontrast yoğunluğu ve çelişkilerden bilgi edinmeyi amaçlayan CRITIC yönteminde, bu iki kaynaktan edinilen ve toplam bilgi olarak adlandırılan $H_{j}$ değeri ne kadar yüksek olursa, karşılık gelen kriter tarafından iletilen bilgi miktarı da o kadar büyük olmaktadır. Eşitlik (5) söz konusu toplam bilgiyi hesaplayabilmek için kullanılmaktadır. 


$$
H_{j}=\sigma_{j} \sum_{k=1}^{m}\left(1-\rho_{j k}\right)
$$

Standart sapma bilgileri, toplam bilgiyi ifade eden $H_{j}$ değerini hesaplamak için kullanılmaktadır. Eşitlik (6) standart sapma değerlerini hesaplamak için kullanılmaktadir.

$$
\sigma_{j}=\sqrt{\sum_{i=1}^{m}\left(r_{i j}-\bar{r}_{j}\right)^{2} /(m-1)}
$$

\section{Adım 5. Kriter ağırlıklarının $\left(w_{j}\right)$ belirlenmesi}

Eşitlik (5) ile ulaşılan kriterlere ait $H_{j}$ değerleri, nihai kriter ağırlıklarını $\left(w_{j}\right)$ hesaplamak için kullanılmaktadır. $H_{j}$ değerinin yükselmesi karar verme süreci için göreceli önemi arttırmaktadır. Eşitlik (7) $w_{j}$ değerlerini hesaplamak için kullanılmaktadır.

$$
w_{j}=H_{j} / \sum_{k=1}^{m} H_{k}
$$

\section{MAIRCA}

Pamučar vd. (2014) tarafından MARICA (Multi-Attributive Real- Ideal Comparative Analysis) adıyla literatüre kazandırılan yöntem, Gigovič vd. (2016) tarafından MAIRCA (Multi-Attributive Ideal-Real Comparative Analysis) olarak isimlendirilerek birçok karar probleminde kullanılmıştır. İdeal ve ampirik ağırlıklar arasındaki boşluğun belirlenmesi ana varsayımıyla çalışan MAIRCA yönteminde, toplam boşluk için en küçük değere sahip alternatif, en fazla sayıda kritere göre ideal ağırlıklara en yakın değerlere sahip olan alternatif (ideal kriter değerleri) olmaktadır. MAIRCA yöntemi altı adımdan oluşan bir çözüm prosedüründen oluşmaktadır:

\section{Adım 1. Karar matrisinin oluşturulması}

Karar matrisi birçok ÇKKV yönteminde benzer şekilde oluşturulmaktadır. Eşitlik (1)'de CRITIC yöntemi için oluşturulan karar matrisi MAIRCA yöntemi için de kullanılmaktadır.

\section{Adım 2. Alternatif tercih olasılığının belirlenmesi}

MAIRCA yönteminde karar vericinin alternatif tercih olasılığı belirlemede tarafsız kaldığı varsayılmaktadır. Yani karar vericinin her bir alternatife eşit uzaklıkta olduğu varsayılmaktadır. Eşitlik (8)' de her bir alternatifin tercih olasılığını ifade eden $P_{A i}$ hesaplanırken toplam alternatif sayısını ifade eden $m$ kullanılmaktadır. Eşitlik (9) ise her bir $P_{A i}$ 'nin eşitliğini göstermektedir. 


$$
\begin{gathered}
P_{A i}=\frac{1}{m} \quad \sum_{i=1}^{m} P_{A i}=1 \quad i=1,2, \ldots, m \\
P_{A 1}=P_{A 2}=\cdots=P_{A m}
\end{gathered}
$$

Adım 3. Teorik değerlendirme matrisi bileşenlerinin hesaplanması $\left(T_{p}\right)$

Teorik değerlendirme matrisi $\left(T_{p}\right)$, n kriter sayısını, m alternatif sayısını gösterecek şekilde oluşturulan $n x m$ formatında bir matristir. Teorik derecelendirme matrisinin öğeleri $\left(t_{p i j}\right)$ tercih olasılıkları $\left(P_{A i}\right)$ ile kriter ă̆ırlıklarının $\left(w_{j}, j=1,2, \ldots, n\right)$ çarpılması ile hesaplanmaktadır. Söz konusu hesaplama ile oluşturulan matris Eşitlik (10)'da gösterilmiştir.

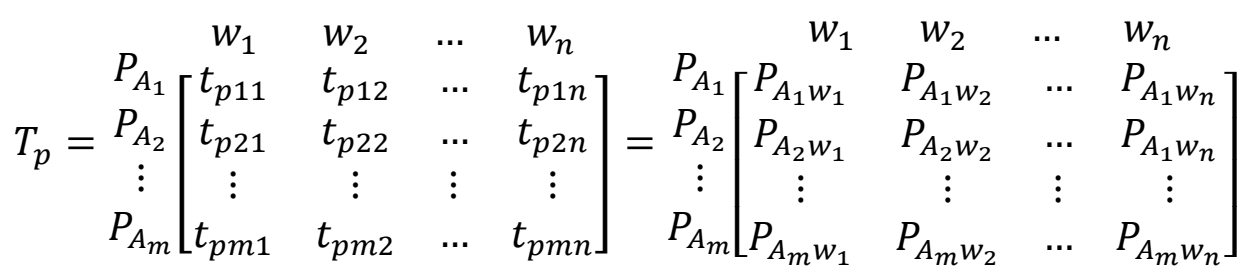

MAIRCA yönteminin doğası gereği karar verici tarafsız olduğundan tercih olasılıkları $\left(P_{A i}\right)$ tüm karar vericiler için eşit olmaktadır. Bundan dolayı Eşitlik (10)'daki nxm formatındaki matris Eşitlik (11)'deki gibi $n \times 1$ formatında gösterilebilir.

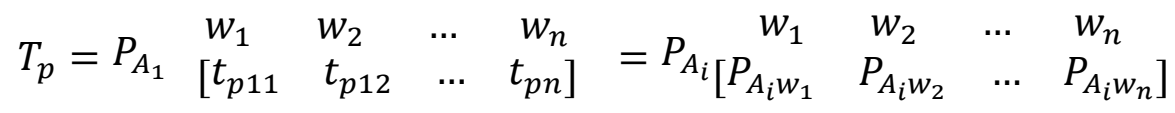

Adım 4. Gerçek değerlendirme matrisinin hesaplanması $\left(T_{r}\right)$

Gerçek değerlendirme matrisinin öğeleri hesaplanırken Eşitlik (10)'da gösterilen teorik değerlendirme matrisi $\left(T_{p}\right)$ ve Eşitlik (1)'de gösterilen başlangıç karar matrisinden yararlanılmaktadır. Eşitlik (12)'de gösterilen gerçek değerlendirme matrisine $\left(T_{r}\right)$ ulaşmak için fayda yönlü (maks) kriterler için Eşitlik (13), maliyet yönlü (min) kriterler için Eşitlik (14) kullanılmaktadır.

$$
\begin{gathered}
T_{r}=\begin{array}{c}
w_{1} \\
A_{2} \\
\vdots \\
A_{m}
\end{array}\left[\begin{array}{cccc}
t_{r 11} & w_{212} & \ldots & t_{n} \\
t_{r 21} & t_{r 22} & \ldots & t_{r 1 n} \\
\vdots & \vdots & \vdots & t_{r 2 n} \\
t_{r m 1} & t_{r m 2} & \ldots & t_{r m n}
\end{array}\right] \\
t_{r i j}=t_{p i j}\left(\frac{x_{i j}-x_{i}^{-}}{x_{i}^{+}-x_{i}^{-}}\right) \\
t_{r i j}=t_{p i j}\left(\frac{x_{i j}-x_{i}^{+}}{x_{i}^{-}-x_{i}^{+}}\right)
\end{gathered}
$$

Eşitlik (13)-(14)'te yer alan $x_{i}^{+}$her bir kritere göre alternatiflerin aldığı en büyük değerleri (maksimum), $x_{i}^{-}$her bir kritere göre alternatiflerin aldığı en küçük değerleri (minimum) ifade etmektedir. 


\section{Adım 5. Toplam boşluk değerleri matrisinin hesaplanması ( $G$ )}

Toplam boşluk değerleri matrisini $(G)$ hesaplarken, teorik değerlendirme matrisindeki değerlerden $\left(t_{p i j}\right)$, gerçek değerlendirme matrisindeki değerler $\left(t_{r i j}\right)$ çıkarılmaktadır. Eşitlik (16) ile hesaplanan değerler Eşitlik (15)'deki gibi gösterilmektedir.

$$
\begin{aligned}
G=T_{p}-T_{r}= & {\left[\begin{array}{cccc}
g_{11} & g_{12} & \ldots & g_{1 n} \\
g_{21} & g_{22} & \ldots & g_{2 n} \\
\vdots & \vdots & \vdots & \vdots \\
g_{m 1} & g_{m 2} & \ldots & g_{m n}
\end{array}\right] } \\
& =\left[\begin{array}{cccc}
t_{p 11}-t_{r 11} & t_{p 12}-t_{r 12} & \ldots & t_{p 1 n}-t_{r 1 n} \\
t_{p 21}-t_{r 21} & t_{p 22}-t_{r 22} & \ldots & t_{p 2 n}-t_{r 2 n} \\
\vdots & \vdots & \vdots & \vdots \\
t_{p m 1}-t_{r m 1} & t_{p m 2}-t_{r m 2} & \ldots & t_{p m n}-t_{r m n}
\end{array}\right] \\
& g_{i j}=t_{p i j}-t_{r i j} \quad g_{i j} \in[0, \infty)
\end{aligned}
$$

Teorik değerlendirme $\left(t_{p i j}\right)$ ile gerçek değerlendirme $\left(t_{r i j}\right)$ arasındaki farkın minimuma inmesi istenen bir durum olduğundan dolayı $g_{i j}{ }^{\prime}$ in sıfıra yaklaşması istenen bir durumdur. Yani $C_{i}$ kriterine ait $A_{i}$ alternatif değerinin teorik değerlendirmesi gerçek değerlendirmesine eşitse $\left(t_{p i j}=t_{r i j}\right)$ boşluk değeri sıfır olacaktır $\left(g_{i j}=0\right)$. Bu durum gerçekleştiğinde $C_{i}$ kriteri için en iyi (ideal) alternatif $A_{i}^{+}$olmaktadır. Fakat eğer herhangi bir $C_{i}$ kriterinin, alternatif $A_{i}$ değerinin teorik değerlendirmesi ile gerçek değerlendirmesi sıfıra eşitse $\left(t_{p i j}=t_{r i j}=g_{i j}=0\right)$, bu alternatif en kötü (anti-ideal) alternatif olmaktadır.

Adım 6. Kriter fonksiyonlarının $\left(Q_{i}\right)$ alternatifler için nihai değerlerinin hesaplanması ve alternatiflerin siralanması

Öncelikle Eşitlik (17) kullanılarak alternatiflerin boşluk değerleri $\left(g_{i j}\right)$ toplanmaktadır. Daha sonra her bir alternatif nihai kriter fonksiyon değerine göre siralanmaktadır. En küçük nihai kriter fonksiyon değerine sahip olan alternatif en iyi alternatiftir.

$$
Q_{i}=\sum_{j=1}^{n} g_{i j} \quad i=1,2, \ldots, m
$$

\section{BULGULAR}

UNESCO Dünya Mirası listesinde destinasyonların bulunduğu illerin turizm potansiyelini değerlendirmek için öncelikle Eşitlik (1)'de gösterildiği şekilde karar matrisi oluşturulmuştur. Tablo 3'te gösterilen karar matrisi hem CRITIC yönteminde hem de MAIRCA yönteminde kullanılmaktadır. 
Tablo 3. Karar matrisi

\begin{tabular}{|c|c|c|c|c|c|c|c|c|}
\hline Kriter yönü & Maks & Maks & Maks & Maks & Maks & Maks & Maks & Maks \\
\hline İller/ Kriterler & $\mathrm{C}_{1}$ & $\mathrm{C}_{2}$ & $\mathrm{C}_{3}$ & $\mathrm{C}_{4}$ & $\mathrm{C}_{5}$ & $\mathrm{C}_{6}$ & $\mathrm{C}_{7}$ & $\mathrm{C}_{8}$ \\
\hline Adiyaman & 37 & 2999 & 28 & 24 & 539 & 1 & 355 & 1597 \\
\hline Aydın & 219 & 41220 & 143 & 183 & 2398 & 12 & 1715 & 27486 \\
\hline Bursa & 265 & 24107 & 401 & 268 & 5239 & 26 & 4709 & 1897 \\
\hline Çanakkale & 424 & 22960 & 64 & 40 & 1381 & 9 & 2847 & 962 \\
\hline Çorum & 50 & 2955 & 24 & 28 & 547 & 3 & 473 & 1140 \\
\hline Denizli & 53 & 7977 & 120 & 56 & 1740 & 3 & 1189 & 4372 \\
\hline Diyarbakır & 53 & 5862 & 71 & 52 & 915 & 5 & 1471 & 10856 \\
\hline Edirne & 125 & 8447 & 39 & 22 & 889 & 10 & 1858 & 505 \\
\hline İstanbul & 2074 & 211140 & 2904 & 3808 & 34399 & 75 & 32176 & 676368 \\
\hline İzmir & 406 & 51356 & 662 & 430 & 10251 & 27 & 8248 & 76577 \\
\hline Karabük & 127 & 3865 & 32 & 19 & 483 & 1 & 2353 & 314 \\
\hline Kars & 59 & 3895 & 14 & 9 & 180 & 2 & 844 & 3193 \\
\hline Konya & 160 & 13521 & 130 & 106 & 2582 & 16 & 2785 & 6716 \\
\hline Muğla & 1313 & 174249 & 276 & 404 & 3703 & 12 & 5512 & 28430 \\
\hline Nevşehir & 434 & 25444 & 26 & 190 & 485 & 8 & 1721 & 3121 \\
\hline Sivas & 69 & 5176 & 40 & 25 & 681 & 3 & 1209 & 3093 \\
\hline Şanlıurfa & 84 & 6720 & 44 & 41 & 583 & 4 & 2502 & 4642 \\
\hline
\end{tabular}

ÇKKV yöntemlerinin birçoğunda farklı birim cinsinden ifade edilen karar kriterlerini 0-1 aralığına indirgemek için normalizasyon işlemi uygulanmaktadır. Bu çalışmada da öncelikle Eşitlik (2) kullanılarak (minimizasyon yönlü kriter olmadığından dolayı Eşitlik (3) kullanılmamıştır) normalizasyon işlemi uygulanmıştır. Normalize edilen kriterler ile oluşturulan normalize karar matrisi Tablo 4'te gösterilmiştir.

Tablo 4. Normalize karar matrisi

\begin{tabular}{lllllllll}
\hline Kriter yönü & Maks & Maks & Maks & Maks & Maks & Maks & Maks & Maks \\
\hline İller/ Kriterler & $\mathrm{C}_{1}$ & $\mathrm{C}_{2}$ & $\mathrm{C}_{3}$ & $\mathrm{C}_{4}$ & $\mathrm{C}_{5}$ & $\mathrm{C}_{6}$ & $\mathrm{C}_{7}$ & $\mathrm{C}_{8}$ \\
\hline Adıyaman & 0,000 & 0,000 & 0,005 & 0,004 & 0,010 & 0,000 & 0,000 & 0,002 \\
\hline Aydın & 0,089 & 0,184 & 0,045 & 0,046 & 0,065 & 0,149 & 0,043 & 0,040 \\
\hline Bursa & 0,112 & 0,102 & 0,134 & 0,068 & 0,148 & 0,338 & 0,137 & 0,002 \\
\hline Çanakkale & 0,190 & 0,096 & 0,017 & 0,008 & 0,035 & 0,108 & 0,078 & 0,001 \\
\hline Çorum & 0,006 & 0,000 & 0,003 & 0,005 & 0,011 & 0,027 & 0,004 & 0,001 \\
\hline Denizli & 0,008 & 0,024 & 0,037 & 0,012 & 0,046 & 0,027 & 0,026 & 0,006 \\
\hline Diyarbakır & 0,008 & 0,014 & 0,020 & 0,011 & 0,021 & 0,054 & 0,035 & 0,016 \\
\hline Edirne & 0,043 & 0,026 & 0,009 & 0,003 & 0,021 & 0,122 & 0,047 & 0,000 \\
\hline İstanbul & 1,000 & 1,000 & 1,000 & 1,000 & 1,000 & 1,000 & 1,000 & 1,000 \\
\hline İzmir & 0,181 & 0,232 & 0,224 & 0,111 & 0,294 & 0,351 & 0,248 & 0,113 \\
\hline Karabük & 0,044 & 0,004 & 0,006 & 0,003 & 0,009 & 0,000 & 0,063 & 0,000
\end{tabular}




\begin{tabular}{lcccccccc}
\hline Kars & 0,011 & 0,005 & 0,000 & 0,000 & 0,000 & 0,014 & 0,015 & 0,004 \\
\hline Konya & 0,060 & 0,051 & 0,040 & 0,026 & 0,070 & 0,203 & 0,076 & 0,009 \\
\hline Muğla & 0,626 & 0,823 & 0,091 & 0,104 & 0,103 & 0,149 & 0,162 & 0,042 \\
\hline Nevşehir & 0,195 & 0,108 & 0,004 & 0,048 & 0,009 & 0,095 & 0,043 & 0,004 \\
\hline Sivas & 0,016 & 0,011 & 0,009 & 0,004 & 0,015 & 0,027 & 0,027 & 0,004 \\
\hline Şanlıurfa & 0,023 & 0,018 & 0,010 & 0,008 & 0,012 & 0,041 & 0,067 & 0,006
\end{tabular}

Normalize edilen kriterler arasındaki korelasyonlara ulaşmak için Eşitlik (4) kullanılmıştır. Ulaşılan korelasyonlardan toplam bilgi ölçüsünü hesaplayabilmek için öncelikle kriterlerin standart sapması Eşitlik (6) kullanılarak hesaplanmıştır. Daha sonra korelasyonlar ve standart sapma değerleri kullanılarak Eşitlik (5) yardımıyla toplam bilgi ölçüsü $\left(H_{j}\right)$ hesaplanmıştır. Son olarak Eşitlik (7) kullanılarak illeri değerlendirmek için kullanılan kriter ağırlıkları $\left(w_{j}\right)$ hesaplanmıştır. Korelasyon değerlerinden oluşan ilişki katsayı matrisi, standart sapma değerleri, toplam bilgi ölçüsü ve kriter ağırlıkları Tablo 5'te gösterilmiştir.

Tablo 5. İlişki katsayı matrisi, standart sapma, toplam bilgi ölçüsü $\left(h_{j}\right)$ ve ağırlıklar $\left(w_{j}\right)$

\begin{tabular}{|c|c|c|c|c|c|c|c|c|}
\hline Kriterler & $\mathrm{C}_{1}$ & $\mathrm{C}_{2}$ & $\mathrm{C}_{3}$ & $\mathrm{C}_{4}$ & $\mathrm{C}_{5}$ & $\mathrm{C}_{6}$ & $\mathrm{C}_{7}$ & $\mathrm{C}_{8}$ \\
\hline $\mathrm{C}_{1}$ & 1 & 0,9773 & 0,8540 & 0,8756 & 0,8490 & 0,8291 & 0,8846 & 0,8427 \\
\hline $\mathrm{C}_{2}$ & 0,9773 & 1 & 0,7931 & 0,8088 & 0,7921 & 0,7707 & 0,8213 & 0,7733 \\
\hline $\mathrm{C}_{3}$ & 0,8540 & 0,7931 & 1 & 0,9901 & 0,9975 & 0,9644 & 0,9942 & 0,9865 \\
\hline $\mathrm{C}_{4}$ & 0,8756 & 0,8088 & 0,9901 & 1 & 0,9801 & 0,9381 & 0,9872 & 0,9957 \\
\hline $\mathrm{C}_{5}$ & 0,8490 & 0,7921 & 0,9975 & 0,9801 & 1 & 0,9727 & 0,9922 & 0,9766 \\
\hline $\mathrm{C}_{6}$ & 0,8291 & 0,7707 & 0,9644 & 0,9381 & 0,9727 & 1 & 0,9621 & 0,9221 \\
\hline $\mathrm{C}_{7}$ & 0,8846 & 0,8213 & 0,9942 & 0,9872 & 0,9922 & 0,9621 & 1 & 0,9811 \\
\hline $\mathrm{C}_{8}$ & 0,8427 & 0,7733 & 0,9865 & 0,9957 & 0,9766 & 0,9221 & 0,9811 & 1 \\
\hline$\sigma_{j}$ & 0,2654 & 0,2929 & 0,2400 & 0,2382 & 0,2408 & 0,2418 & 0,2350 & 0,2404 \\
\hline$H_{j}$ & 0,2356 & 0,3700 & 0,1008 & 0,1011 & 0,1059 & 0,1550 & 0,0886 & 0,1255 \\
\hline$w_{j}$ & 0,1837 & 0,2885 & 0,0786 & 0,0788 & 0,0826 & 0,1208 & 0,0691 & 0,0978 \\
\hline
\end{tabular}

CRITIC yöntemi ile kriter ağırlıklarına ulaşıldıktan sonra MAIRCA yöntemi ile iller değerlendirilmiştir. Kriterlerin değerlendirilmesine yine Eşitlik (1) yardımı ile oluşturulan Tablo 1'deki karar matrisi ile başlanmıştır. Öncelikle alternatif tercih olasılığını $\left(P_{A i}\right)$ hesaplamak için Eşitlik (8) kullanılmıştır. MAIRCA yönteminde karar vericilerin her bir alternatife eşit uzaklıkta olduğu varsayıldığından dolayı $P_{A i}$ değeri her bir alternatif için eşittir $\left(P_{A i}=0,058824\right)$. Daha sonra CRITIC yöntemi ile hesaplanan kriter ağırlıkları $\left(w_{j}\right)$ ve alternatif tercih olasılıkları $\left(P_{A i}\right)$ kullanılarak Eşitlik (10) yardımıyla teorik derecelendirme değerleri hesaplanmıştır. Bu değerler kullanılarak oluşturulan teorik derecelendirme matrisi Tablo 6'da gösterilmiştir. 
Tablo 6. Teorik derecelendirme matrisi $\left(T_{p}\right)$

\begin{tabular}{|c|c|c|c|c|c|c|c|c|}
\hline Kriter yönü & Maks & Maks & Maks & Maks & Maks & Maks & Maks & Maks \\
\hline İller/ Kriterler & $\mathrm{C}_{1}$ & $\mathrm{C}_{2}$ & $\mathrm{C}_{3}$ & $\mathrm{C}_{4}$ & $\mathrm{C}_{5}$ & $\mathrm{C}_{6}$ & $\mathrm{C}_{7}$ & $\mathrm{C}_{8}$ \\
\hline Adiyaman & 0,0108 & 0,0170 & 0,0046 & 0,0046 & 0,0049 & 0,0071 & 0,0041 & 0,0058 \\
\hline Aydın & 0,0108 & 0,0170 & 0,0046 & 0,0046 & 0,0049 & 0,0071 & 0,0041 & 0,0058 \\
\hline Bursa & 0,0108 & 0,0170 & 0,0046 & 0,0046 & 0,0049 & 0,0071 & 0,0041 & 0,0058 \\
\hline Çanakkale & 0,0108 & 0,0170 & 0,0046 & 0,0046 & 0,0049 & 0,0071 & 0,0041 & 0,0058 \\
\hline Çorum & 0,0108 & 0,0170 & 0,0046 & 0,0046 & 0,0049 & 0,0071 & 0,0041 & 0,0058 \\
\hline Denizli & 0,0108 & 0,0170 & 0,0046 & 0,0046 & 0,0049 & 0,0071 & 0,0041 & 0,0058 \\
\hline Diyarbakır & 0,0108 & 0,0170 & 0,0046 & 0,0046 & 0,0049 & 0,0071 & 0,0041 & 0,0058 \\
\hline Edirne & 0,0108 & 0,0170 & 0,0046 & 0,0046 & 0,0049 & 0,0071 & 0,0041 & 0,0058 \\
\hline İstanbul & 0,0108 & 0,0170 & 0,0046 & 0,0046 & 0,0049 & 0,0071 & 0,0041 & 0,0058 \\
\hline İzmir & 0,0108 & 0,0170 & 0,0046 & 0,0046 & 0,0049 & 0,0071 & 0,0041 & 0,0058 \\
\hline Karabük & 0,0108 & 0,0170 & 0,0046 & 0,0046 & 0,0049 & 0,0071 & 0,0041 & 0,0058 \\
\hline Kars & 0,0108 & 0,0170 & 0,0046 & 0,0046 & 0,0049 & 0,0071 & 0,0041 & 0,0058 \\
\hline Konya & 0,0108 & 0,0170 & 0,0046 & 0,0046 & 0,0049 & 0,0071 & 0,0041 & 0,0058 \\
\hline Muğla & 0,0108 & 0,0170 & 0,0046 & 0,0046 & 0,0049 & 0,0071 & 0,0041 & 0,0058 \\
\hline Nevşehir & 0,0108 & 0,0170 & 0,0046 & 0,0046 & 0,0049 & 0,0071 & 0,0041 & 0,0058 \\
\hline Sivas & 0,0108 & 0,0170 & 0,0046 & 0,0046 & 0,0049 & 0,0071 & 0,0041 & 0,0058 \\
\hline Şanlıurfa & 0,0108 & 0,0170 & 0,0046 & 0,0046 & 0,0049 & 0,0071 & 0,0041 & 0,0058 \\
\hline
\end{tabular}

Sonraki aşamada gerçek derecelendirme matrisini (Tr) oluşturmak için Eşitlik (13) (minimizasyon yönlü kriter olmadığından dolayı Eşitlik (14) kullanılmamıştır) kullanılmıştır. Gerçek değerlendirme matrisi hesaplanırken teorik derecelendirme matrisi $\left(T_{p}\right)$ ve karar matrisi (Tablo 3) öğeleri kullanılmıştır. Eşitlik (12)'de gösterildiği şekilde oluşturulan gerçek derecelendirme matrisi Tablo 7'de verilmiştir.

Tablo 7. Gerçek derecelendirme matrisi ( $\mathrm{Tr}$ )

\begin{tabular}{lllllllll}
\hline Kriter yönü & Maks & Maks & Maks & Maks & Maks & Maks & Maks & Maks \\
\hline İler/ Kriterler & $C_{1}$ & $C_{2}$ & $C_{3}$ & $C_{4}$ & $C_{5}$ & $C_{6}$ & $C_{7}$ & $C_{8}$ \\
\hline Adıyaman & 0,0000 & 0,0000 & 0,0000 & 0,0000 & 0,0001 & 0,0000 & 0,0000 & 0,0000 \\
\hline Aydın & 0,0010 & 0,0031 & 0,0002 & 0,0002 & 0,0003 & 0,0011 & 0,0002 & 0,0002 \\
\hline Bursa & 0,0012 & 0,0017 & 0,0006 & 0,0003 & 0,0007 & 0,0024 & 0,0006 & 0,0000 \\
\hline Çanakkale & 0,0021 & 0,0016 & 0,0001 & 0,0000 & 0,0002 & 0,0008 & 0,0003 & 0,0000 \\
\hline Çorum & 0,0001 & 0,0000 & 0,0000 & 0,0000 & 0,0001 & 0,0002 & 0,0000 & 0,0000 \\
\hline Denizli & 0,0001 & 0,0004 & 0,0002 & 0,0001 & 0,0002 & 0,0002 & 0,0001 & 0,0000 \\
\hline Diyarbakır & 0,0001 & 0,0002 & 0,0001 & 0,0001 & 0,0001 & 0,0004 & 0,0001 & 0,0001 \\
\hline Edirne & 0,0005 & 0,0004 & 0,0000 & 0,0000 & 0,0001 & 0,0009 & 0,0002 & 0,0000 \\
\hline İstanbul & 0,0108 & 0,0170 & 0,0046 & 0,0046 & 0,0049 & 0,0071 & 0,0041 & 0,0058 \\
\hline İzmir & 0,0020 & 0,0039 & 0,0010 & 0,0005 & 0,0014 & 0,0025 & 0,0010 & 0,0006 \\
\hline
\end{tabular}




\begin{tabular}{lcccccccc}
\hline Karabük & 0,0005 & 0,0001 & 0,0000 & 0,0000 & 0,0000 & 0,0000 & 0,0003 & 0,0000 \\
\hline Kars & 0,0001 & 0,0001 & 0,0000 & 0,0000 & 0,0000 & 0,0001 & 0,0001 & 0,0000 \\
\hline Konya & 0,0007 & 0,0009 & 0,0002 & 0,0001 & 0,0003 & 0,0014 & 0,0003 & 0,0001 \\
\hline Muğla & 0,0068 & 0,0140 & 0,0004 & 0,0005 & 0,0005 & 0,0011 & 0,0007 & 0,0002 \\
\hline Nevşehir & 0,0021 & 0,0018 & 0,0000 & 0,0002 & 0,0000 & 0,0007 & 0,0002 & 0,0000 \\
\hline Sivas & 0,0002 & 0,0002 & 0,0000 & 0,0000 & 0,0001 & 0,0002 & 0,0001 & 0,0000 \\
\hline Şanlıurfa & 0,0002 & 0,0003 & 0,0000 & 0,0000 & 0,0001 & 0,0003 & 0,0003 & 0,0000
\end{tabular}

Sonraki aşamada toplam boşluk değerleri matrisinin elemanlarını hesaplamak için teorik derecelendirme matrisi $\left(T_{p}\right)$ ve gerçek derecelendirme matrisi $\left(T_{r}\right)$ elemanları kullanılmıştır. Eşitlik (16) kullanılarak hesaplanan değerler Eşitlik (15)'deki matris şeklinde gösterilmiştir. Son olarak boşluk değerleri Eşitlik (17)’de gösterildiği şekilde toplanarak alternatiflerin nihai değerlerine $\left(Q_{i}\right)$ ulaşılmıştır. Toplam boşluk değerleri matrisi, alternatiflerin nihai değerleri ve illerin sıralaması Tablo 8'de gösterilmiştir.

Tablo 8. Toplam boşluk değerleri matrisi $(g)$, alternatiflerin nihai değerleri $\left(q_{i}\right)$ ve sıralamalar

\begin{tabular}{|c|c|c|c|c|c|c|c|c|c|c|}
\hline Kriter yönü & Maks & Maks & Maks & Maks & Maks & Maks & Maks & Maks & \multirow{2}{*}{$Q_{i}$} & \multirow{2}{*}{ Siralama } \\
\hline İller/ Kriterler & $\mathrm{C}_{1}$ & $\mathrm{C}_{2}$ & $\mathrm{C}_{3}$ & $\mathrm{C}_{4}$ & $\mathrm{C}_{5}$ & $\mathrm{C}_{6}$ & $\mathrm{C}_{7}$ & $\mathrm{C}_{8}$ & & \\
\hline Adiyaman & 0,0108 & 0,0170 & 0,0046 & 0,0046 & 0,0048 & 0,0071 & 0,0041 & 0,0057 & 0,0587 & 17 \\
\hline Aydın & 0,0098 & 0,0139 & 0,0044 & 0,0044 & 0,0045 & 0,0061 & 0,0039 & 0,0055 & 0,0525 & 5 \\
\hline Bursa & 0,0096 & 0,0152 & 0,0040 & 0,0043 & 0,0041 & 0,0047 & 0,0035 & 0,0057 & 0,0513 & 4 \\
\hline Çanakkale & 0,0088 & 0,0153 & 0,0045 & 0,0046 & 0,0047 & 0,0063 & 0,0037 & 0,0057 & 0,0538 & 7 \\
\hline Çorum & 0,0107 & 0,0170 & 0,0046 & 0,0046 & 0,0048 & 0,0069 & 0,0041 & 0,0057 & 0,0584 & 16 \\
\hline Denizli & 0,0107 & 0,0166 & 0,0045 & 0,0046 & 0,0046 & 0,0069 & 0,0040 & 0,0057 & 0,0575 & 11 \\
\hline Diyarbakır & 0,0107 & 0,0167 & 0,0045 & 0,0046 & 0,0048 & 0,0067 & 0,0039 & 0,0057 & 0,0576 & 12 \\
\hline Edirne & 0,0103 & 0,0165 & 0,0046 & 0,0046 & 0,0048 & 0,0062 & 0,0039 & 0,0058 & 0,0567 & 9 \\
\hline İstanbul & 0,0000 & 0,0000 & 0,0000 & 0,0000 & 0,0000 & 0,0000 & 0,0000 & 0,0000 & 0,0000 & 1 \\
\hline İzmir & 0,0088 & 0,0130 & 0,0036 & 0,0041 & 0,0034 & 0,0046 & 0,0031 & 0,0051 & 0,0458 & 3 \\
\hline Karabük & 0,0103 & 0,0169 & 0,0046 & 0,0046 & 0,0048 & 0,0071 & 0,0038 & 0,0058 & 0,0579 & 13 \\
\hline Kars & 0,0107 & 0,0169 & 0,0046 & 0,0046 & 0,0049 & 0,0070 & 0,0040 & 0,0057 & 0,0584 & 15 \\
\hline Konya & 0,0102 & 0,0161 & 0,0044 & 0,0045 & 0,0045 & 0,0057 & 0,0038 & 0,0057 & 0,0549 & 8 \\
\hline Muğla & 0,0040 & 0,0030 & 0,0042 & 0,0042 & 0,0044 & 0,0061 & 0,0034 & 0,0055 & 0,0347 & 2 \\
\hline Nevşehir & 0,0087 & 0,0151 & 0,0046 & 0,0044 & 0,0048 & 0,0064 & 0,0039 & 0,0057 & 0,0537 & 6 \\
\hline Sivas & 0,0106 & 0,0168 & 0,0046 & 0,0046 & 0,0048 & 0,0069 & 0,0040 & 0,0057 & 0,0580 & 14 \\
\hline Şanlıurfa & 0,0106 & 0,0167 & 0,0046 & 0,0046 & 0,0048 & 0,0068 & 0,0038 & 0,0057 & 0,0575 & 10 \\
\hline
\end{tabular}

Tablo 7'de gösterilen UNESCO Dünya Mirası listesinde yer alan tarihi mekanların bulunduğu destinasyonlar arasında yapılan değerlendirme sonuçlarına göre ilk sırada İstanbul yer almıştır. Tüm kriterler için teorik derecelendirme değeri ile gerçek derecelendirme değeri eşit olarak bulunan İstanbul tüm kriterler açısından en iyi performansı göstermiştir. İstanbul'u sırasıyla Muğla, İzmir ve Bursa izlemiştir. En 
kötü performansı gösteren iller ise sırasıyla Sivas, Kars, Çorum ve Adıyaman olmuştur.

\section{Duyarlılık Analizi}

CRITIC ve MAIRCA yöntemleri kullanılarak gerçekleştirilen değerlendirmenin doğruluğunu ve tutarlılığını test etmek adına bir duyarlılık analizi gerçekleştirilmiştir. Yapılan duyarlılık analizi çerçevesinde CRITIC yöntemi ile ulaşılan ağırlıklar kullanilarak, COPRAS (Complex Proportional Assessment), MABAC (MultiAttributive Border Approximation area Comparison), ARAS (Additive Ratio ASsessment) ve WASPAS (Weighted Aggregated Sum Product Assessment) yöntemleri ile yeniden çözümler yapılmıştır. Yapılan çözümler sonucunda ulaşılan siralamalar ve MAIRCA yöntemi ile ulaşılan sıralamalar ile diğer yöntemler ile ulaşılan sıralamalar arasındaki sıra korelasyonu (Spearman's Rho) değerleri Tablo 9' da gösterilmiştir.

Tablo 9. Duyarlılık analizi

\begin{tabular}{|c|c|c|c|c|}
\hline İller/Yöntemler & COPRAS & MABAC & ARAS & WASPAS \\
\hline Adiyaman & 17 & 17 & 17 & 17 \\
\hline Aydın & 5 & 5 & 5 & 5 \\
\hline Bursa & 4 & 4 & 4 & 4 \\
\hline Çanakkale & 7 & 7 & 7 & 7 \\
\hline Çorum & 15 & 16 & 15 & 15 \\
\hline Denizli & 10 & 11 & 10 & 10 \\
\hline Diyarbakır & 12 & 12 & 12 & 12 \\
\hline Edirne & 9 & 9 & 9 & 9 \\
\hline İstanbul & 1 & 1 & 1 & 1 \\
\hline İzmir & 3 & 3 & 3 & 3 \\
\hline Karabük & 13 & 13 & 13 & 14 \\
\hline Kars & 16 & 15 & 16 & 16 \\
\hline Konya & 8 & 8 & 8 & 8 \\
\hline Muğla & 2 & 2 & 2 & 2 \\
\hline Nevşehir & 6 & 6 & 6 & 6 \\
\hline Sivas & 14 & 14 & 14 & 13 \\
\hline Şanlıurfa & 11 & 10 & 11 & 11 \\
\hline $\begin{array}{l}\text { Spearman's Rho } \\
\text { (MAIRCA) }\end{array}$ & $0,995^{*}$ & $1,000^{*}$ & $0,995^{*}$ & $0,993^{*}$ \\
\hline
\end{tabular}

Tablo 8' de yer alan sonuçlar incelendiğinde MAIRCA yöntemi ile ulaşılan sıralamalar ile diğer yöntemler kullanılarak ulaşılan sıralamalar arasında çok büyük benzerlikler olduğu sonucuna varılmıştır. Özellikle MABAC yöntemi ile ulaşılan sıralama ile MAIRCA yöntemi ile ulaşılan sıralamalar aynı sonucu vermiştir. Diğer yöntemler ile ulaşılan sıralamalar ile MAIRCA yöntemi ile ulaşılan sıralamalar arasında ise mükemmele yakın anlamlı korelasyonlar saptanmıştır. Bu sonuç göz önüne alınarak 
diğer çözümler ile benzer sonuçlara ulaşılmasından dolayı yapılan analizin tutarlı ve doğru bir analiz olduğu söylenebilmektedir.

\section{SONUÇ, TARTIŞMA VE ÖNERİLER}

Bu çalışmada Türkiye'de UNESCO Dünya Mirası listesinde yer alan destinasyonların bulunduğu iller turizm potansiyeli açısından değerlendirilmiştir. Bir ilde veya bölgede kültür turizm faaliyetinin etkin bir şekilde gerçekleşebilmesi için tek başına o bölgenin kültürel varlıklarının zengin olması yeterli olamamaktadır. Etkin bir kültür turizmi için kültürel faaliyetin gerçekleştiği destinasyonun bulunduğu yerde veya yakınlarında turizm faaliyeti gerçekleştirmeye uygun altyapı ve üstyapı olanaklarının da gelişmiş olması gerekmektedir. Bu motivasyon ile tasarlanan çalışmada ÇKKV yöntemlerinden CRITIC ve MAIRCA kullanılarak iller değerlendirilmiştir.

Literatür dikkate alınarak seçilen kriterler objektif ÇKKV yöntemlerinden CRITIC kullanılarak ağırlıklandırılmıştır. Elde edilen bulgulara göre en önemli kriter yatak sayısı $\left(w_{2}=0,2885\right)$ olarak bulunmuştur. Bu kriteri sirasıyla otel sayısı $\left(w_{1}=0,1837\right)$, müze sayısı $\left(w_{6}=0,1208\right)$, bir yıldaki uçuş sayısı $\left(w_{8}=0,0978\right)$, yiyecek-içecek işyeri sayısı $\left(w_{5}=0,0826\right)$, seyahat acentesi-tur operatörü işyeri sayısı $\left(w_{4}=0,0788\right)$, spor-eğlencedinlence işyeri sayısı $\left(w_{3}=0,0786\right)$ ve tarihi yapı ve sit alanları sayısı $\left(w_{7}=0,0691\right)$ kriterleri izlemiştir. En önemli kriterler kültür turizmi faaliyetine katılacak turistler için en temel ihtiyaç olan konaklama faaliyetini temsil eden kriterlerdir. Diğer kriterlerin ağırlıkları incelendiğinde birbirine benzer ağırlıkların ortaya çıktığı gözlemlenmektedir.

CRITIC yöntemi ile elde edilen ağırlıklar kullanılarak MAIRCA yöntemi ile illerin sıralamalarına ulaşılmıştır. Elde edilen bulgulara göre turizm potansiyeli açısından sırasıyla en başarılı iller İstanbul, Muğla, İzmir, Bursa ve Aydın, en başarısız iller Karabük, Sivas, Kars, Çorum ve Adıyaman olmuştur. Sıralamalar incelendiğinde başarılı illerin hepsi büyükşehir statüsündeyken, başarısız illerin hiçbiri büyükşehir statüsünde değildir. Ayrıca dikkat çeken diğer bir bulgu da başarılı illerin tamamının denize kıyısı olan illerden oluşmasıdır. Bu bulgular bu illerde turizm potansiyeli oluşması için gerekli olan alt ve üst yapı olanaklarının sadece o bölgede yer alan kültürel varlıklar ile açıklanamayacağının kanıtıdır. Büyükşehir statüsündeki başarılı iller kültür turizmi yanında diğer turizm türlerinin de yoğun olarak gerçekleştiği (özellikle İstanbul ve Bursa için iş turizmi, Muğla, İzmir ve Aydın için yaz turizmi) illerdir. Başarısız olan iller için ise turizmin kaynağı sadece o ilde bulunan kültür varlığıdır. Başarısız olan bu illerdeki müze, tarihi yapı ve sit alanı sayılarının değerlendirmede yer alan tüm illerin ortalamasının çok altında değerlere sahip olması da bu durumu doğrular niteliktedir. Örneğin Sivas'ta yer alan Divriği Ulu Camii ve Darüşşifası ve Çorum'da yer alan Hattuşa: Hitit Başkenti Türkiye'den UNESCO Dünya Mirası listesine alınan ilk eserlerden olmasına rağmen Sivas'ta ve Çorum'da yalnızca üçer tane müze yer almaktadır. Yani başarısız illerin turistlere sunacağı UNESCO Dünya Mirası listesinde yer alan destinasyonlar haricinde fazla bir varlığı bulunmamaktadır. Bundan dolayı bu kültür varlıklarının UNESCO Dünya Mirası listesine alınmasının üzerinden çok uzun yıllar geçmiş olmasına rağmen illerin turizm 
potansiyelinin artmasına yeterince katkı sağlayamamıştır. Başarılı illere gelen turistlerin ise UNESCO Dünya Mirası listesindeki varlıkların haricinde birçok kültürel ve turistik faaliyete katılması mümkündür.

Elde edilen bu bulgular turizmin gelişmesinin yalnızca o bölgede yer alan kültür varlıkları ile ilişkilendirilemeyeceği gerçeğini ortaya koymaktadır. Bu bulgular 1şığında turizm karar vericilerine yönetimsel bazı çıkarımlar önerilmektedir. Öncelikle reklam ve tanıtım faaliyetlerinin turizm potansiyeli artışındaki etkisi iyi analiz edilmelidir. Başarısız olan illerdeki turizm potansiyelinin gelişmemesi söz konusu ildeki turistik alt ve üst yapı eksiklikleri kadar reklam ve tanıtım eksiklikleri ile de ilgilidir. Örneğin dünyadaki en büyük dijital yayın platformlarından birisi olan Netflix'de son yıllarda UNESCO Dünya Mirası listesinde de yer alan bazı destinasyonların kullanıldığı (İstanbul'un tarihi mekânları ve Göbeklitepe) yayın içerikleri hazırlanmıştır. Bu bölgelerden İstanbul hem tanıtım ve pazarlama hem de turizm potansiyeli açısından kendisini kanıtlamış bir il olmasına rağmen Göbeklitepe' nin yer aldığı Şanlıurfa için büyük bir tanıtım vesilesi olmuştur. Özellikle Netflix gibi hemen hemen tüm dünyada yayın yapan dijital içerik platformlarında bu gibi içeriklerin daha fazla hazırlanmasına katkı sağlamak bu destinasyonların tüm dünyada tanınırlığını artıracaktır.

Turizm gelirlerinin toplam Gayri Safi Milli Hasıla (GSMH) içerisindeki payı 2019 yılında \%4,6 olarak gerçekleşmiştir (TUİK, 2020). Bu yüksek gelir ancak sürdürülebilir bir harcama ile sürdürülebilir bir gelir haline getirilebilir. Bu yüzden politika yapıcılar sadece bazı turizm türlerine (deniz turizmi, dağ turizmi, termal turizm vb.) yatırım yapmak yerine tüm turizm türlerine kaynak ayrılması hususunda karar almalıdır. Özellikle bu analiz sonucunda başarısız olarak bulunan illerde turizm potansiyeli oluşturabilmek adına bu illere daha fazla alt ve üst yapı yatırımları yapılmalıdır. Bununla birlikte 2019 yılının Aralık ayında Çin'in Wuhan eyaletinde ortaya çıkarak kısa sürede dünyanın her yerini etkisi altına alan Covid-19 pandemisi tüm faaliyetleri etkilediği gibi turizm faaliyetini de derinden etkilemiştir. Birçok ülkenin turizm gelirleri düşmüş, bölgesel ve uluslararası insan dolaşımı minimuma inmiştir. Bu dönemde ortaya çıkan uluslararası turizm hareketliliğindeki duraksama yerli turistin öneminin arttırılması gerektiğini göstermiştir. Bu ve bunun gibi olağanüstü durumlar göz önünde bulundurularak uluslararası turiste sağlanan imkân ve kolaylıklar yerli turistlere de sağlanmalıdır.

Her araştırmada olduğu gibi bu araştırmada da bazı kısıtlılıklar mevcuttur. Zaman ve kaynak kısıtlılıklarından dolayı sınırlı sayıda değerlendirme kriteri kullanılabilmiştir. Gelecek çalışmalarda bu çalışmada kullanılan nicel kriterler, bölgedeki uzmanlardan edinilen nitel veriler ile desteklenebilir. Ayrıca bu çalışmada uzman görüşlerinin kullanılmadığı objektif ÇKKV yöntemleri kullanılmıştır. Gelecek çalışmalarda uzman görüşlerinin de kullanıldığı ÇKKV yöntemleri tercih edilebilir. Son olarak bu çalışmada sadece Türkiye'de yer alan UNESCO Dünya Mirası listesindeki kültürel varlıkların bulunduğu bölgeler değerlendirilmiştir. Gelecekte yapılacak çalışmalarda daha fazla sayıda bölge değerlendirmeye tabi tutulabilir. 
Hakem Değerlendirmesi: Dış bağımsız.

Teşekkür: Katkılarından dolayı hakemlere teşekkür ederiz.

Destek Bilgisi: Herhangi bir kurum ve/veya kuruluştan destek alınmamıştır.

Çıkar Çatışması: Yazarlar arasında çıkar çatışması yoktur.

Etik Onayı: Bu çalışmanın tüm hazırlanma süreçlerinde etik kurallara riayet edildiğini yazar(lar) beyan eder. Aksi bir durumun tespiti halinde Güncel Turizm Araştırmaları
Dergisi'nin hiçbir sorumluluğu olmayıp, tüm sorumluluk makale yazar(lar)ına aittir.

Bilgilendirilmiş Onam Formu: Tüm taraflar kendi rızaları ile çalışmaya dâhil olmuşlardır.

Etik Kurul Onayı: Çalışma kamuya açık ikincil verilerin kullanılmasıyla oluşturulmuştur.

Araştırmacıların Katkı Oranı: Yazarlar çalışmaya eşit oranda katkı sağlamıştır.

Veri Kullanılabilirlik Beyanı: Araştırma verileri paylaşılmamıştır.

\section{KAYNAKÇA}

Akbulut, O. Y. (2019). CRITIC ve EDAS yöntemleri ile İş Bankası'nın 2009-2018 yılları arasındaki performansının analizi. Ekonomi Politika ve Finans Araştırmaları Dergisi, $4(2), 249-263$.

Aksoy, A., ve Ünsal, D. (2012). Kültürel Miras Yönetimi. Eskişehir: Anadolu Üniversitesi Yayınları.

Apan, M., ve Öztel, A. (2020). Girişim sermayesi yatırım ortaklıklarının CRITIC-PROMETHEE bütünleşik karar verme yöntemi ile finansal performans değerlendirmesi: Borsa İstanbul'da bir uygulama. Dumlupınar Üniversitesi Sosyal Bilimler Dergisi, 63, 54-73.

Arsić, S. N., Pamučar, D., Suknović, M., ve Janošević, M. (2019). Menu evaluation based on rough MAIRCA and BW methods. Serbian journal of management, 14(1), 27-48.

Ayçin, E., (2020). Personel seçim sürecinde CRITIC ve MAIRCA yöntemlerinin kullanılması, İşletme, 1(1), 1-12.

Ayçin, E., ve Güçlü, P. (2020). BIST ticaret endeksinde yer alan işletmelerin finansal performanslarının Entropi ve MAIRCA yöntemleri ile değerlendirilmesi. Muhasebe ve Finansman Dergisi, (85), 287-312.

Ayçin, E., ve Orçun, Ç. (2019). Mevduat bankalarının performanslarının Entropi ve MAIRCA yöntemleri ile değerlendirilmesi. Balıkesir Üniversitesi Sosyal Bilimler Enstitüsü Dergisi, 22(42), 175-194.

Aydın, Y. (2020) Bütünleşik CRITIC ve MAIRCA yöntemleri ile kamu sermayeli bankalarının performans analizi. Finans Ekonomi ve Sosyal Araştırmalar Dergisi, 5(4), 829-841.

Ayrım, Y., ve Can, G. F. (2017). Risk değerlendirmesinde CRITIC metodu ile sektörlerin karşılaştırması. Journal of Turkish Operations Management, 1(1), 67-78.

Bachleitner, Reinhard ve Zins, Andreas. H. (1999). Cultural tourism in rural communities: The residents perspective. Journal of Business Research, 44(3), 199-209.

Baldemir, E., ve Akyurt Kurnaz, H. (2013). İlçelerin turizm potansiyellerinin analitik hiyerarşi yöntemi ile sıralanması: Muğla örneği. Muğla Üniversitesi Sosyal Bilimler Enstitüsü Dergisi, (30), 51-67. 
Bandeoğlu, Z. (2015). Türkiye'de kültür turizmi potansiyeli üzerine bir değerlendirme. Kahramanmaraş Sütçü İmam Üniversitesi İktisadi ve İdari Bilimler Fakültesi Dergisi, 5(2), 155-168.

Bektaş, S. (2020). Mevduat bankalarının finansal performanslarının sıralanması: Türk mevduat bankalarının CRITIC ve MAIRCA yöntemleriyle performans analizi. Akademik İncelemeler Dergisi, 15(2), 793-822.

Belke, M. (2020). CRITIC ve MAIRCA yöntemleriyle G7 ülkelerinin makroekonomik performansının değerlendirilmesi. İstanbul Ticaret Üniversitesi Sosyal Bilimler Dergisi, 19 Temmuz 2020 (Özel Sayı), 120-139.

Boniface, P., ve Fowler, P. (2002). Heritage and Tourism in the Global Village. Routledge.

Božanić, D., Jurišić, D., ve Erkić, D. (2020). LBWA-Z-MAIRCA model supporting decision making in the army. Operational Research in Engineering Sciences: Theory and Applications, 3(2), 87-110.

Can, G. F., ve Kıran, M. B. (2020). Occupational health and safety performance evaluation of countries based on MAIRCA. International Journal of Intelligent Computing and Cybernetics, 13(1), 1-24.

Ceylan, S., ve Somuncu, M. (2016). Kültür turizmi alanlarında turizmi çeşitlendirilmesine eleştirel bir bakış: Safranbolu UNESCO dünya miras alanı. Uluslararası Türk Dünyası Turizm Araştırmaları Dergisi, 1(1), 53-64.

Chatterjee, K., Pamučar, D., ve Zavadskas, E. K. (2018). Evaluating the performance of suppliers based on using the R'AMATEL-MAIRCA method for green supply chain implementation in electronics industry. Journal of cleaner production, 184, 101-129.

Cracolici, M. F., Nijkamp, P., ve Rietveld, P. (2008). Assessment of tourism competitiveness by analysing destination efficiency. Tourism economics, 14(2), 325-342.

Çağlar, Z., ve Doğan, M. (2018). UNESCO dünya miras listelerinin turizm arzına etkisi: Diyarbakır örneği. Journal of Tourism and Gastronomy Studies, 6(3), 455-471.

Cuccia, T., Guccio, C., ve Rizzo, I. (2016). The effects of UNESCO World Heritage List inscription on tourism destinations performance in Italian regions. Economic Modelling,53, 494-508.

Çulha, O. (2008). Kültür turizmi kapsamında destekleyici turistik ürün olarak deve güreşi festivalleri üzerine bir alan çalışması, Journal of Yaşar University, 3(12), 1827-1852.

Devlet Hava Meydanları İşletmesi Genel Müdürlüğü (DHMI) (2021). Havalimanları Karşılaştırmalı İstatistikleri.

[URL: https://www.dhmi.gov.tr/Sayfalar/Istatistikler.aspx] (Erişim Tarihi: 7 Mart 2021).

Diakoulaki, D., Mavrotas, G., ve Papayannakis, L. (1995). Determining objective weights in multiple criteria problems: The CRITIC method. Computers \& Operations Research, 22(7), 763-770.

Do, T. H. N., ve Shih, W. (2016). Destination decision-making process based on a hybrid MCDM model combining DEMATEL and ANP: The Case of Vietnam as a Destination. Modern Economy, 7(9), 966-983. 
Dwyer, L., ve Kim, C. (2003). Destination competitiveness: Determinants and indicators. Current issues in tourism, 6(5), 369-414.

Fedajev, A., Popović, G., ve Stanujkić, D. (2019). MCDM framework for evaluation of the tourism destination competitiveness. In Proc. of 5th International scientific conference Innovation as an initiator of the development-MEFkon, 5 Aralık 2019, Belgrade, Serbia, pp. 112-119.

Genç, T., ve Filipe, J. A. (2016). A fuzzy MCDM approach for choosing a tourism destination in Portugal. International Journal of Business and Systems Research, 10(1), 23-44.

Gigović, L., Pamučar, D., Bajić, Z., ve Milićević, M. (2016). The combination of expert judgment and GIS-MAIRCA analysis for the selection of sites for ammunition depots. Sustainability, 8(372), 1-30.

Giritlioğlu, ̇̇., İpar, M. S., ve Özlü, B. (2015). Turizm ve bölgesel kalkınma ilişkisi: TRC1 bölgesi üzerine bir inceleme. Uluslararası Hakemli Beşeri ve Akademik Bilimler Dergisi (UHBAB Journal), 4(14), 216-237.

Goeldner, C., ve Ritchie, J. (2009). Tourism: Principles, Practices, Philosophies. New Jersey: Hoboken.

Günay, F., ve Ecer, F. (2020). Cash flow based financial performance of Borsa İstanbul tourism companies by Entropy-MAIRCA integrated model. Journal of Multidisciplinary Academic Tourism, 5(1), 29-37.

Hazar, A. (2010). Genel Turizm. Ankara: Nobel Yayın Dağıtım.

İstanbul Tarihi Alanları Alan Başkanlığı, (2021). [URL: http://www.alanbaskanligi.gov.tr/dunya_miras_kavrami.html]. (Erişim Tarihi: 01 Nisan 2012).

Jafari, J. (2002). Encyclopedia of Tourism. Routledge.

Kervankıran, İ., ve Sert Eteman, F. (2020). Turizm ve bölgesel gelişme: Türkiye'de illerin turizm gelişmişlik düzeylerinin belirlenmesi. Ege Coğrafya Dergisi, 29(2), 125-140.

Keshavarz Ghorabaee, M., Amiri, M., Zavadskas, E. K., ve Antuchevičienè, J. (2017). Assessment of third-party logistics providers using a CRITIC-WASPAS approach with interval type-2 fuzzy sets. Transport, 32(1), 66-78.

Keshavarz Ghorabaee, M., Amiri, M., Zavadskas, E. K., ve Antuchevičienė, J. (2018). A new hybrid fuzzy MCDM approach for evaluation of construction equipment with sustainability considerations. Archives of Civil and Mechanical Engineering, 18, 32-49.

Khakzad, S., Pieters, M., ve Van Balen, K. (2015). Coastal cultural heritage: A resource

to be included in integrated coastal zone management. Ocean \&Coastal Management, 118, 110128.

Kültür ve Turizm Bakanlığ1 (KTB) (2021). Turizm İstatistikleri. [URL: https://yigm.ktb.gov.tr/TR-9851/turizm-istatistikleri.html] (Erişim Tarihi: 1 Mart 2021).

Lopez-Guzman, T., ve Santa-Cruz, F. G. (2016). International tourism and the UNESCO category of intangible cultural heritage. International Journal of Culture, Tourism and Hospitality Research, 10(3), 310-322. 
Mamak Ekinci, E. B., ve Can, G. F. (2018). Algılanan iş yükü ve çalışma duruşları dikkate alınarak operatörlerin ergonomik risk düzeylerinin çok kriterli karar verme yaklaşımı ile değerlendirilmesi. Ergonomi, 1(2), 77-91.

Martín, J. C., Mendoza, C., ve Román, C. (2017). A DEA travel-tourism competitiveness index. Social Indicators Research, 130(3), 937-957.

Medlik, S. (2003). Dictionary of Travel, Tourism and Hospitality. UK: ButterworthHeinemann.

Meydan Uygur, S., ve Baykan, E. (2007). Kültür turizmi ve turizmin kültürel varlıklar üzerindeki etkileri. Ticaret ve Turizm Eğitim Fakültesi Dergisi, 2(1), 30-49.

Operational Guidelines for the Implementation of the World Heritage Convention, (2019). United Nations Educational, Scientific and Cultural Organization, Intergovernmental Committee for the Protection of the World Cultural and Natural Heritage. [URL: https://whc.unesco.org/en/guidelines/]. (Erişim Tarihi: 25 Mart 2021).

Orhan M. ve Aytekin M. (2020). Türkiye ile AB'ye son katılan ülkelerin Ar-Ge performanslarının CRITIC ağırlıklı MAUT ve SAW yöntemiyle kıyaslanması. Business \& Management Studies: An International Journal, 8(1), 754-778.

Öksüz Kuşçuoğlu, G. ve Taş, M. (2017). Sürdürülebilir kültürel miras yönetimi. Süleyman Demirel Üniversitesi Yalvaç Akademi Dergisi 2(1), 58-67.

Özdağoğlu, A., Keleş, M. K., ve Işıldak, B. (2020). Isparta Süleyman Demirel Havalimanını kullanan havayolu firmaları performanslarinın BWM, MAIRCA ve MABAC ile değerlendirilmesi. Uluslararası İktisadi ve İdari İncelemeler Dergisi, (29), 175-194.

Pamučar, D., Lukovac, V., Božanić, D., ve Komazec, N. (2018). Multi-criteria FUCOMMAIRCA model for the evaluation of level crossings: case study in the Republic of Serbia. Operational Research in Engineering Sciences: Theory and Applications, 1(1), 108-129.

Pamučar, D., Vasin, L., ve Lukovac, L. (2014, October). Selection of railway level crossings for investing in security equipment using hybrid DEMATEL-MARICA model. In XVI International Scientific-Expert Conference on Railway, RAILCON, Belgrade, Serbia, pp. 89-92.

Peng, X., Zhang, X., ve Luo, Z. (2020). Pythagorean fuzzy MCDM method based on CoCoSo and CRITIC with score function for 5G industry evaluation. Artificial Intelligence Review, 53, 3813-3847.

Richards, G. (2001). The Development of Cultural Tourism in Europe. Richards (Ed.), içinde Cultural Attractions and European Tourism (s.3-30). Cabi.

Seçilmiş, C., ve Sarı, Y. (2010). Türkiye'de illerin turizm gelişmişlik endeksinin oluşturulmasına yönelik bir araştırma. Elektronik Sosyal Bilimler Dergisi, 9(32), 117132.

Sosyal Güvenlik Kurumu (SGK) (2021). SGK İstatistik Yıllıkları. [URL: http://www.sgk.gov.tr/wps/portal/sgk/tr/kurumsal/istatistik/sgk_istatistik_yilliklari] (Erişim Tarihi: 10 Mart 2021). 
Şenol, Z., ve Ulutaş, A. (2018). Muhasebe temelli performans ölçümleri ile piyasa temelli performans ölçümlerinin CRITIC ve ARAS yöntemleriyle değerlendirilmesi. Finans Politik \& Ekonomik Yorumlar, 55(641), 83-102.

The United Nations World Tourism Organization (UNWTO). (2021). [URL:https://www.unwto.org/archive/global/publication/tourism-world-heritagesites-challenges-and-opportunities]. (Erişim Tarihi: 22 Mart 2012).

Türker, A. ve Çelik, İ. (2012). Somut olmayan kültürel miras unsurlarının turistik ürün olarak geliştirilmesine yönelik alternatif öneriler. Yeni Fikir, 9, 86-98.

Türkiye İstatistik Kurumu (TUİ) (2021). Kültürel Miras İstatistikleri. [URL: https://tuikweb.tuik.gov.tr/PreHaberBultenleri.do?id=33633] (Erişim Tarihi: 7 Mart 2021)

Ulutaş, A. (2019). SWARA ve MAIRCA yöntemleri ile catering firması seçimi. Business \& Management Studies: An International Journal, 7(4), 1467-1479.

Ulutaş, A., ve Karaköy, Ç. (2019). CRITIC ve ROV yöntemleri ile bir kargo firmasının 20112017 yılları sırasındaki performansının analiz edilmesi. MANAS Sosyal Araştırmalar Dergisi, 8(1), 223-230.

United Nations Educational, Scientific and Cultural Organization (UNESCO), (2021). [URL: https://whc.unesco.org/en/about/]. (Erişim Tarihi: 23 Mart 2012).

United Nations Educational, Scientific and Cultural Organization (UNESCO), (2021). [URL: https://www.unwto.org/tourism-and-culture]. (Erişim Tarihi: 27 Mart 2021).

United Nations Educational, Scientific and Cultural Organization (UNESCO), (2021). [URL: https://whc.unesco.org/en/list/]. (Erişim Tarihi: 03 Nisan 2021).

Uslu, A. ve Kiper, T. (2006). Turizmin kültürel miras üzerine etkileri: Beypazarı/Ankara örneğinde yerel halkın farkındalığı. Tekirdağ Ziraat Fakültesi Dergisi 3(3), 305-314.

Usta, Ö. (2009). Turizm: Genel ve Yapısal Yaklaşım. Ankara: Detay Yayıncılık.

Vujičić, M. D., Papić, M. Z., ve Blagojević, M. D. (2017). Comparative analysis of objective techniques for criteria weighing in two MCDM methods on example of an air conditioner selection. Tehnika, 72(3), 422-429.

Xu, C., Ke, Y., Li, Y., Chu, H., ve Wu, Y. (2020). Data-driven configuration optimization of an off-grid wind/PV/hydrogen system based on modified NSGA-II and CRITIC-TOPSIS. Energy Conversion and Management, 215, 112892.

Yalçın, N., ve Karakaş, E. (2019) Kurumsal Sürdürülebilirlik Performans Analizinde CRITICEDAS Yaklaşımı. Çukurova Üniversitesi Mühendislik-Mimarlık Fakültesi Dergisi, 34(4), 147-162.

Yeniş̧ehirlioğlu, E., ve Arslan Kalay, H. (2017). UNESCO Dünya Miras Listesi'nin kültürel miras alanlarındaki ziyaretçi sayılarına etkisi. In: International Congress On Cultural Heritage and Tourism (ICCHT 2017), 1191-1198. 